\title{
Na jakie pytania mógłby odpowiedzieć tworzony w 2. dekadzie XXI w. model leksykalno- -derywacyjny polszczyzny XX w.?
}

\section{Investigating 2oth-century Polish by means of a lexico-derivational model designed in the second decade of the 21th century}

\author{
Piotr Wierzchoń \\ INSTYTUT JĘZYKOZNAWSTWA, UNIWERSYTET IM. ADAMA MICKIEWICZA, \\ AL. NIEPODLEGŁOŚCI 4, 61-874 POZNAŃ \\ wierzch@amu.edu.pl
}

\begin{abstract}
This paper discusses a project to develop a lexico-derivational model of 2oth-century Polish vocabulary. On the one hand, this model should be constructed in accordance with the Polish tradition of great lexico-derivational models such as Satkiewicz 1969, Smółkowa 1976, Jadacka 2001 and Waszakowa 2005. On the other hand, it should take into consideration new empirical material gained from the application of linguochronoligization theory (TLCH). A crucial part in the construction of the new model is played by lexical material from the first half of the 2oth century, which by the end of the first decade of the 21st century was available only in very limited quantity, most of it coming from systematic, long-term extraction research carried out by Jan Wawrzyńczyk. Therefore this article describes the milestones which have led to the present state, in which it is possible to formulate a plan for the development of such a model. Moreover, the limitations and shortcomings of previous lexico-derivational models are discussed. As a result, a list of 37 questions which could be answered by the emerging model of Polish vocabulary is given. Also, selected graphs are presented to illustrate the diachronic dynamics of Polish vocabulary in the first half of the 2oth century.
\end{abstract}

\section{Cel pracy}

Celem artykułu jest przedyskutowanie zasadności i praktycznej wykonalności konstrukcji leksykalno-derywacyjnego modelu polszczyzny XX w. w nawiązaniu do polskiej tradycji wielkich modeli leksykalno-derywacyjnych (np. Satkiewicz 1969, Smółkowa 1976, Jadacka 2001, Waszakowa 2005 itp.). Z kategorią praktycznej wykonalności łączy się pojęcie ograniczenia czasowego. 
Piotr Wierzchoń: Na jakie pytania mógtby odpowiedzieć tworzony $w$ 2. dekadzie XXI $w$. model leksykalno-derywacyjny polszczyzny XX $w$.?

Ludwik Fleck, autor komplementowanej przez Thomasa S. Kuhna monografii Entstehung und Entwicklung einer wissenschaftlichen Tatsache. Einführung in die Lehre vom Denkstil und Denkkollektiv, pisze w pracy O obserwacji naukowej i postrzeganiu wogóle (ort. oryg. - P.W.):

Do niedawna panowało niepodzielnie wśród przyrodników przekonanie, wyrażone w zdaniu Poincarégo: „gdyby badacz rozporządzał nieskończonym czasem, wystarczyłoby powiedzieć mu: Patrz, a patrz dobrze". Z opisu jego obserwacyj wszystkich zdarzeń miałaby wyniknąć cała wiedza (Fleck 1935: 58).

Wiemy, że badacz, językoznawca, nie rozporządza nieskończonym czasem obserwacji. W praktyce $\mathrm{w}$ celu przygotowania modelu leksykalno-derywacyjnego danej epoki, wieku, półwiecza czy wybranych dekad - rezerwuje się kilka lat efektywnej, w zamierzeniu nieprzerwanej, pracy naukowej (przy czym kumulacja wiedzy niezbędnej do podjęcia czynności analitycznych może obejmować okres nawet kilkudziesięciu lat; co więcej, przeważnie im dłuższy jest okres „umysłowego” przygotowania, tym krótszy jest okres ostatecznej, tj. „manualnej” pracy twórczej, uwieńczonej w praktyce - konkretnym dzielem naukowym).

Aby skonstruować taki model, należy uprzednio sformułować teorię (przede wszystkim: parametry oglądu, czyli wspomnianego wyżej „patrzenia”), która będzie określała, o czym w teorii tej można mówić. W rezultacie model tu omawiany składa się z elementów rzeczywistości (tekst polski XX w., np. w postaci zbioru czasopism), którą opisuje się przy użyciu zaproponowanej teorii.

Tak więc teoria, której aplikacja może doprowadzić do uzyskania modelu, nazywanego także modelem właściwym (por. np. Przełęcki 1993, Pogonowski 1991, Grobler 2001), zakłada dwuetapowe przebadanie bazy empirycznej w postaci obiektów: jednostek leksykalnych wyekscerpowanych z tekstów XX w. Przez przebadanie w pierwszym etapie rozumie się bezwyjątkowe określenie wszystkich obiektów $\mathrm{w}$ założonych $\mathrm{w}$ teorii parametrach ekscerpcyjno-chronologizacyjnych, tj. ze względu na:

a) czas występowania jednostek języka (data wydania czasopisma),

b) tematykę czasopisma,

c) geografię występowania jednostek języka (rozumianą inaczej niż w ujęciu np. J. Gilliérona i E. Edmonta z roku 1902, ponieważ związaną ściśle i wyłącznie z miejscem publikacji czasopisma),

d) lokalizacja jednostek języka w tekście (np. numer strony czasopisma),

e) typ prasoznawczy czasopisma (periodyczność czasopisma).

Stąd jednostki leksykalne z tekstów XX w. grupuje się w zbiory określone ze względu na kryteria-parametry:

a) chronologizacyjne,

b) tematyczne (prasa kobieca, czasopisma techniczne, krajoznawcze, hobbystyczne i inne), 
c) geograficzne,

d) prasoznawcze:

- periodyzacyjne (dziennik, tygodnik, miesięcznik, rocznik itp.),

- lokalizacyjne w tekście (numer strony).

Podział ten skutkuje uzyskaniem materiału empirycznego w postaci schronologizowanych oraz określonych tekstologicznie zbiorów (a-d) jednostek wraz z informacją frekwencyjną.

$\mathrm{W}$ drugim etapie tak scharakteryzowane jednostki poddane zostaną analizie w nowych parametrach (leksykalno-derywacyjnych):

a) frekwencyjnych,

b) segmentacyjnych (morfologicznych),

c) semantycznych (kategorie nazw),

d) ortograficznych (pisownia),

e) pochodnościowych (pochodność od nazw obcych lub nieobcych),

f) techniki derywacji (derywaty afiksalne a bezafiksalne),

g) itp.

A zatem jednostki te poddane będą analizie frekwencyjnej, leksykalnej (leksykologicznej), pochodnościowej, derywacyjnej (zgodnie z duchem teorii Jadacka 2001, Waszakowa 2005 oraz z nowymi parametrami zaproponowanymi przez piszącego te słowa, które ten dostrzegł podczas analizy materiału XX w.).

W praktyce, przez projektowany i przedstawiony do dyskusji model leksykalno-derywacyjny polszczyzny XX w. rozumie się tu wzbogaconą wersję modeli wielkich typu: Satkiewicz 1969, Smółkowa 1976, Jadacka 2001, Waszakowa 2005, Kwapień 2010 itp.

Wzbogacenie modeli typu Jadacka 2001 czy Waszakowa 2005 oznacza kontynuację obszernych dociekań np. H. Jadackiej i K. Waszakowej oraz:

a) rozszerzenie obserwacji leksykalno-diachronicznej na okres 1901-2000 ,

b) radykalny wzrost liczby obiektów leksykalnych poddawanych analizie (z około 3000-5000 do około 50 000-100 000; wielkość tej bazy jest kwestią otwartą),

c) istotny wzrost parametrów leksykalno-derywacyjnych, przy użyciu których zamierza się charakteryzować obiekty bazy empirycznej,

d) minimalizację entropii opisu: oddzielenie komponentu kwantytatywnego (pogrupowane podzbiory obiektów modelu, np. derywatów) od komponentu interpretacji (np. w zakresie możliwych przyczyn tzw. specjalizacji i zatraty specjalizacji formantów, wzrostu inwentarza morfemów, zmiany zbiorów jednostek fundujących itd.). 
Piotr Wierzchoń: Na jakie pytania mógtby odpowiedzieć tworzony $w$ 2. dekadzie XXI $w$. model leksykalno-derywacyjny polszczyzny XX $w$.?

Wynikiem pracy, na którą składa się komponent:

a) ekscerpcyjno-chronologizacyjny (analiza chronologizacyjna tekstu XX w. w celu uzyskania np. wniosków, które pozwolą, kolejno, na efektywną ekscerpcję derywatów z tekstów XX w.),

b) leksykalno-derywatologiczny (analiza leksykalno-słowotwórcza derywatu XX w. w celu uzyskania wniosków, które pozwolą na efektywną ocenę ewolucyjną systemu leksykalnego polszczyzny XX w.),

jest synteza dotycząca ewolucji omawianego systemu XX w., a więc model postleksykograficzny. Celem budowy takiej syntezy jest zrozumienie fenomenu polszczyzny $\mathbf{X X} \mathbf{~ w}$. w jej przejawie leksykalno-derywacyjnym ze względu na jedną z możliwych teorii, dzięki której poznanie to się dokonuje.

\section{Wyjściowe założenia aksjologiczne}

Poniższe założenia traktuje się jako punkt wyjścia w dyskusji nad zasadnością podjęcia pracy nad projektem opisu leksykalno-derywacyjnego polszczyzny XX w. w 2. dekadzie XXI w. Założenia te mają charakter postulatywny. Zanegowanie ich czyni dalszą lekturę projektu bezprzedmiotową.

\section{Po1 (Postulat bazowy)}

Polszczyznę XX w. należy badać.

\section{Po2 (Postulat maksymalizacji)}

Polszczyznę XX w. należy badać w jej możliwie bogatym przejawie ilustracji materiałowej.

\section{Po3 (Postulat uszezegółowienia maksymalizacji)}

Możliwie bogaty przejaw ilustracji materiałowej szacuje się ze względu na osiągalne w danym roku maksimum empiryczne przygotowania projektu teorii, której aplikacja doprowadzi do uzyskania modelu (obecnie: 2. dekada XXI w.).

\section{Po4 (Postulat tradycji)}

Istnieje polska tradycja konstrukcji pewnego typu modelu leksykalno-derywacyjnego. Cechą modeli w tej tradycji jest: a) wykorzystanie materiału leksykograficznego, b) neonimiczność określana leksykograficznie, c) objętość ok. 3000-500o jednostek, d) przewaga uwzględniania eksplikacji strukturalno-znaczeniowej derywatu (vs. eksplikacja „warszawsko-toruńska”, tj. np. w strukturze tematyczno-rematycznej). 


\section{Po5 (Postulat regeneracji modelu)}

Celem odnawiania istniejącego dla danego przedziału czasu modelu leksykalno-derywacyjnego jest uzyskanie coraz wierniejszego (aproksymacja prawdy) obrazu rzeczywistości (tu: rzeczywistości tekstowej XX w.). Wzrost wierności odwzorowania uzyskuje się poprzez: a) zwiększenie bazy empirycznej, b) zwiększenie liczby parametrów, w których opisuje się indywidua bazy empirycznej, c) zwiększenie liczby cech $\mathrm{w}$ parametrach (w których opisuje się indywidua bazy empirycznej).

\section{Po6 (Postulat unikania rejestru leksykograficznego)}

Dynamiki systemu leksykalnego i derywacyjnego XX w. nie należy już (2. dekada XXI w.) badać na podstawie analizy zbioru hasel leksykograficznych słownika ogólnego.

\section{Po7 (Postulat atrakcji tekstu)}

Dynamikę tę, rozumianą jako wielkość zmiany (przyrostu i zmniejszania się) liczby indywiduów badanych w dowolnych, odpowiednio zaprojektowanych parametrach oglądu (teorii; zwłaszcza w ramach teorii, do których przywykł już polski użytkownik modeli) w danym przedziale czasu (np. 1901-2000), określa się poprzez analizę sumy jednostek schronologizowanego tekstu polskiego.

\section{Po8 (Postulat rangi tekstu)}

Im bliżej współczesności, a dalej od okresu staropolszczyzny (por. np. Dunaj 2010: 55, pkt 5), tym dane leksykograficzne pobrane ze słowników ogólnych języka, np. polskiego, bardziej tracą na wartości, gdyż coraz słabiej odzwierciedlają własności systemu językowego, który zamierza się badać w polskiej tradycji konstrukcji tego typu modeli leksykalno-derywacyjnych.

\section{Po9 (Postulat szczegółowości skali diachronicznej)}

W celu opracowania na przełomie 1. i 2. dekady XXI w. modelu leksykalno-derywacyjnego polszczyzny tekst polski XX w., z którego zostaną wyodrębnione jednostki leksykalne poddawane badaniu, winien być schronologizowany z dokładnością co najmniej roczną.

\section{Po1o (Postulat demokratyzacji badań naukowych)}

Materiał empiryczny służący do konstrukcji bazy wykorzystywanej do budowy modelu musi być dostępny wszystkim zainteresowanym $\mathbf{w}$ identyczny sposób. 
Piotr Wierzchoń: Na jakie pytania mógtby odpowiedzieć tworzony $w$ 2. dekadzie XXI $w$. model leksykalno-derywacyjny polszczyzny XX $w$.?

\section{Po11 (Postulat szczegółowy 1.)}

Jedynym na świecie źródłem tych danych, pozyskiwalnych do pewnego stopnia w sposób zautomatyzowany, a więc wykonalny, jest na przełomie 1. i 2. dekady XXI w. system dLibra.

\section{Po12 (Postulat konfidencji)}

Należy dążyć do najdogodniejszej dla wspólnoty naukowej prezentacji bazy empirycznej modelu. Optymalną formą tej prezentacji (nawet za cenę zwiększenia objętości publikacji) jest obecnie dla materiału graficznego XX w. - fotodokumentacja, tzn. ukazanie fragmentu zeskanowanego tekstu z kontekstem jednostki leksykalnej poddawanej analizie leksykalno-derywacyjnej (por. Wierzchoń 2008).

\section{Po13 (Postulat pierwodruku)}

Chronologizowany materiał leksykalny winien być pobrany głównie z czasopisma jako rodzaju pierwodruku.

\section{Po14 (Postulat racjonalności)}

Teoria prowadząca do osiągnięcia modelu winna uwzględniać tylko takie parametry, które są intersubiektywnie pojmowalne i doświadczalne, tzn. poprzez wykonanie analogicznego badania, doświadczenia, analizy itp.

\section{Po15 (Postulat unikania bezsensowności i straty czasu)}

Teoria, która prowadzi do uzyskania modelu leksykalno-derywacyjnego polszczyzny XX w., musi zawierać tylko takie parametry, które będą sprawiedliwie („prawdolubnie”) ocenione przez jej twórcę jako istotne dla poznania badanego systemu, np. derywacyjnego.

\section{Po16 (Postulat optymalizacji teorii gromadzenia materiału)}

Optymalne rozwiązanie problemu opisu (i interpretacji) dynamiki leksykalno-derywacyjnej systemu polszczyzny XX w. sporządzanego w polskiej tradycji modeli leksykalno-derywacyjnych jest uzależnione od uprzedniego sformułowania optymalnej teorii ekscerpcji i chronologizacji materiału polszczyzny $\mathrm{XX}$ w.

\section{Po17 (Postulat szczegółowy 2.)}

Teorią językoznawstwa stosowanego, pozwalającą obecnie na prześledzenie systemu XX w. tak badanego, tj. badanego ze względu na tę tradycję, o takim zamierzeniu, jest teoria lingwochronologizacyjna ( $\boldsymbol{T L C H}$; por. np. Wierzchoń 2008). Teoria ta pozwala na totalne gromadzenie schronologizowanego materiału empirycznego $\mathrm{w}$ postaci jednostek leksykalnych okresu 1901-2000. 


\section{Po18 (Postulat sprawiedliwości w tradycji)}

Zarówno liczba i charakter parametrów teorii, jak i rozmiar bazy empirycznej, której elementy mają być przebadane $\mathrm{w}$ parametrach teorii, powinny być wymagane (jednocześnie) co najwyżej w zgodzie z dotychczasową tradycją wielkich model leksykalno-derywacyjnych; innymi słowy: nie można żądać od wielkiego modelu szczegółowości eksplikacji w trybie „warszawsko-toruńskim”, jak również nie można od mikromodelu o wyżej wskazanej szczegółowości eksplikacji semantyczno-pragmatycznej (w strukturze atrybutywno-relacyjnej, predykatowo-argumentowej, tematyczno-rematycznej, syntagmatyczno-paradygmatycznej itp.) żądać przyjęcia bazy materiałowej liczącej kilka tysięcy indywiduów przeznaczonych do eksplikacji semantyczno-pragmatycznej (w strukturze atrybutywno-relacyjnej, predykatowo-argumentowej, tematyczno-rematycznej, syntagmatyczno-paradygmatycznej itp.).

\section{Po19 (Postulat wykonalności)}

Teoria, w której ujmuje się parametry opisu polszczyzny XX w., musi być wyłącznie niesprzeczna, natomiast projekt modelu wyznaczanego tą teorią musi być praktycznie wykonalny.

\section{Po2o (Postulat uszczegółowienia wykonalności)}

Przez wykonalność rozumie się możliwość realizacji modelu w ciągu kilkudziesięciu miesięcy.

Przystępując do dalszej lektury projektu modelu leksykalno-derywacyjnego polszczyzny XX w., należy zaakceptować powyższe postulaty. Brak akceptacji tych postulatów przerywa kontakt z kolejnymi partiami tekstu.

\section{Kamienie milowe, które w sposób konieczny prowadzą do modelu polszczyzny XX w.}

Konstruowanie modelu leksykalno-derywacyjnego polszczyzny XX w. wymaga zaangażowania dwu teorii:

a) lingwochronologizacyjnej,

b) derywatologicznej.

Powstanie wielkiego modelu polszczyzny XX w. poprzedzone jest żmudnym, wieloletnim dochodzeniem do stanu obecnego, w którym możliwe jest postawienie pytania o próbę podjęcia konstrukcji takiego modelu. Do ważniejszych wydarzeń z historii opisów polszczyzny XX w. można zaliczyć m.in. poniższe. W roku 1987 J. Wawrzyńczyk pisze:

W dyskusji nad projektem nowego słownika warto rozważyć kwestię, czy nie powinno się przystąpić do opracowania 
Piotr Wierzchoń: Na jakie pytania mógtby odpowiedzieć tworzony $w$ 2. dekadzie XXI $w$. model leksykalno-derywacyjny polszczyzny XX $w$.?

t e z a u r u s a, który by zawarł słownictwo drukowanych tekstów polskich powstałych po roku 1900.

W roku 2001 na okładce pracy H. Jadackiej czytamy:

Książka jest pierwszym syntetycznym spojrzeniem na rzeczywistość słowotwórczą ostatniego półwiecza. Opisuje nowe słownictwo powojenne w kontekście takich czynników rozwoju słowotwórczego, jak przemiany polityczne, gospodarcze, społeczne i kulturalne. Na pewno zainteresuje studentów filologii, językoznawców, nauczycieli oraz wszystkich miłośników języka (Jadacka 2001: z okładki).

W roku 2005 na okładce pracy K. Waszakowej czytamy:

(...) monografia Krystyny Waszakowej to pozycja szczególna w polskim słowotwórstwie (Waszakowa 2005: z okładki - Prof. dr hab. Krystyna Kleszczowa).

(...) Sądzę, że po ukazaniu się tej książki będzie po nią sięgał każdy autor i wykładowca zajmujący się czy to ogólną problematyką słowotwórstwa, problematyką neologizmów

(...) (Waszakowa 2005: z okładki - Prof. dr hab. Jadwiga Puzynina).

W roku 2010 piszący te słowa zwraca uwagę na następującą kwestię:

Zacieśnianie współpracy badaczy, np. H. Jadackiej, K. Waszakowej, J. Wawrzyńczyka czy P. Wierzchonia, mogłoby dać imponujące wyniki ekscerpcyjne, odsłonić nieznane obszary leksyki XX w., jak i rozpalić naukową dyskusję (na akademickim poziomie) nad f e n o m e n e m słownictwa XX w.

Kto wsiada, a kto gapi się...

Cennym wkładem w opis rzeczywistości polszczyzny XX w. (odwołując się do wspomnianej polskiej tradycji wielkich modeli) są również modele T. Smółkowej i D. Tekiel (Smółkowa 1976, Smółkowa, Tekiel 1977), H. Satkiewicz (1969) i in. Nowy rozdział w strukturze wielkich modeli leksykalno-derywacyjnych otworzył M. Szczyszek, poświęcając swoją monografię przyrostkowi -owicz (Szczyszek 2006).

\section{Krytyka teorii lingwochronologizacyjnych i mo- deli lingwochronograficznych (lata 1992-2008)}

Omawiane tu modele polszczyzny XX w. dzielą się na takie,

a) w których mówi się o neonimiczności badanego materiału względem danej granicy datacji, np. 1945 r. (por. Smółkowa 1976), oraz takie,

b) w których nie traktuje się analizowanego materiału jako powstałego po danej dacie (por. np. Mędelska 2004). 
W wypadku tych pierwszych modeli ocena chronologizacji badanych jednostek wynika z przyjętej teorii chronologizacji.

W latach 1992-2008 J. Wawrzyńczyk poddaje krytyce teorię lingwochronologizacyjną T. Smółkowej:

W roku 1992:

Moje opracowanie ma wyłącznie źródłowo-dokumentacyjny charakter i przeznaczone jest dla badaczy rozwoju leksyki nowopolskiej świadomych konieczności weryfikacji zawartych w obszernej już literaturze przedmiotu poglądów na chronologię najnowszych warstw słownictwa polskiego i jego ewolucji semantycznej (...) (Wawrzyńczyk 1992: 3).

W roku 1994:

W 1992 roku opublikowałem nakładem Uniwersytetu Mikołaja Kopernika w Toruniu pracę pt. Chronologizacja stownictwa nowopolskiego. W poszukiwaniu źródet dokumentacyjnych neologizmów powojennych, powodowany tym, że «akademickie» poglądy na tzw. nowe słownictwo polskie, ogłoszone $\mathrm{w}$ latach siedemdziesiątych, upowszechniły się i są ogólnie uznawane (...) (Wawrzyńczyk 1994: 5).

W roku 1999:

Zastanawiałem się, dlaczego moje próby skorygowania lingwistycznej opinio vulgaris o rozwoju zasobu słownictwa nowopolskiego okazały się nieskuteczne, dlaczego nadal utrzymują się fałszywe wyobrażenia o losach wielu tysięcy jednostek leksykalnych, nadal nie pamięta się o tym, że procesy żywiołowego przyrostu słownictwa mają w polszczyźnie dłuższą historię, obejmują całą pierwszą połowę wieku XX, a także wiek XIX (Wawrzyńczyk 1999: 4).

W roku 2008:

O szkodach, jakie polskiej lingwochronografii przynoszą p r z e d w c z e ś n i e podejmowane prace badawcze, które utrwala się w druku pod chwytliwymi tytułami w rodzaju Nowe stownictwo polskie. Materiaty z prasy lat 1985-1992, pisałem już wiele razy, ze skutkiem nienadzwyczajnym, gdyż nadal ukazują się prace naukowe oraz publikacje podręcznikowe, przede wszystkim akademickie, przywołujące całkowicie bezkrytycznie literaturę przedmiotu z kluczowym terminem czy też paraterminem «nowe słownictwo polskie» (Wawrzyńczyk 2008: 3). 
Piotr Wierzchoń: Na jakie pytania mógtby odpowiedzieć tworzony $w$ 2. dekadzie XXI $w$. model leksykalno-derywacyjny polszczyzny XX $w$.?

Krytyka J. Wawrzyńczyka w latach 1992-2008 teorii T. Smółkowej nie odnosi żadnego skutku. W roku 2010 ukazuje się seria IV Nowego stownictwa polskiego, wykorzystująca dotychczasową metodologię chronologizacji polszczyzny powojennej, polegającą na wykorzystywaniu kryterium leksykograficznego nowości.

\section{Krytyka teorii lingwochronologizacyjnych i mo- deli lingwochronograficznych (lata 2008-2011)}

W latach 2008-2011 piszący te słowa wskazuje mankamenty modeli współczesnej polszczyzny, a zwłaszcza modeli H. Jadackiej (2001) i K. Waszakowej (2005), ponieważ głównie te dwa modele - ze względu na zaawansowane, czytelne formy referowania teorii - poddają się krytyce.

W roku 2008 P. Wierzchoń zestawil inwentarz sufiksów modelu Jadacka 2001 z okresu powojennego i po roku 1989 (dla uproszczenia ilustracji podaje się jedynie sufiksy o nagłosie konsonantycznym):

\begin{tabular}{|l|l|}
\hline \multicolumn{1}{|c|}{$\begin{array}{c}\text { Sufiksy po 1945 r. } \\
\text { (nagłos konsonantyczny) }\end{array}$} & \multicolumn{1}{c|}{$\begin{array}{c}\text { sufiksy po 1989 r. } \\
\text { (nagłos konsonantyczny) }\end{array}$} \\
\hline -nia & -nia \\
\hline -ka & -ka \\
\hline -stwo & -stwo \\
\hline -nik & -nik \\
\hline -nica & -(j)ada \\
\hline -ca & -ca \\
\hline
\end{tabular}

Tabela 1. Porównanie dwu grup wybranych sufiksów z modelu Jadacka 2001

Wynika z powyższego, że jedynym sufiksem o nagłosie z rozszerzeniem konsonantycznym, który znika ze strefy I-III w modelu Jadacka 2001 $\mathrm{z}$ okresu powojennego, jest -nica, a jedynym, który się pojawia (mowa o strefie I-III) po roku 1989, jest -(j)ada.

Dodatkowy problem leży w warstwie opisowej Jadacka 2001: mówi się tam o „może nawet wzrastającej produktywności” (Jadacka 2001: 84). Zgodnie $\mathrm{z}$ wynikiem porównania danych kwantytatywnych ze strony 43 i 77, -(j)ada istotnie wzrasta (powojenne poniżej 5 derywatów na strefę III - wynik 10; czyli wzrost: ponownie tyle).

Piszący te słowa stan ten uznał za zastanawiający - przy czym w żadnym wypadku nie podważa się tego, że wynik analizy materiału H. Jadackiej jest poprawny. Nie ma wątpliwości, że jest to wynik poprawny względem zgromadzonej bazy empirycznej, ale w roku 2008 nasunęła się inna wątpliwość - czy baza empiryczna, skolekcjonowana w celu uzyskania takich a takich wyników, była skolekcjonowana poprawnie? A jeżeli byłaby skolekcjonowania niepoprawnie, co miałaby znaczyć owa niepoprawność? Jak ją rozumieć? Co to jest poprawność bazy empirycznej wielkich modeli wypracowanych w polskiej tradycji, od której to bazy wychodzi się do 
analiz morfologicznych (kategorie morfologiczne) czy leksykalnych (kategorie nazw) itp.?

Od tej chwili piszący te słowa rozpoczyna mozolne analizy modeli współczesnej polszczyzny, tj. polszczyzny po roku 1945. Drążenie tego tematu (tematu: teorii i praktyki weryfikacji materiału leksykalnego w badaniach lingwistycznych) doprowadziło do szeregu ustaleń, które z dnia na dzień dawały pełniejszą odpowiedź na pytanie: dlaczego opis, który ujmuje się w omawianych modelach polszczyzny, przedstawia się tak a tak (np. że po roku 1989 w strefie I-III pojawia się jedynie -(j)ada).

Doszło tu do intrygującego splotu okoliczności: zakładając nawet, że faktycznie jedynym morfemem o nagłosie konsonantycznym, który wszedł do strefy III po roku 1989, jest -(j)ada, to należy powiedzieć, że podczas analizy tego problemu pojawiły się trudności innego typu - chronologizacyjnego.

Efekt tych rozważań przyjął formę gramatyki chronologizacyjnej, która zrodziła teorię lingwochronologizacji (TLCH). Podobnie do np. niemieckich ujęć tzw. gramatyki treści (por. neohumboldtyzm), w której opisywano wzajemne zależności semantyczne jednostek leksykalnych i ich zbiorów, gramatyka chronologizacji skoncentrowana jest na opisie wzajemnych zależności chronologizacyjnych jednostek leksykalnych i ich zbiorów. Wynikiem działania np. gramatyki treści jest sporządzenie modelu pól semantycznych (np. jednostek leksykalnych połączonych cechą semantyczną), a wynikiem działania np. gramatyki chronologizacyjnej jest sporządzenie modelu pól chronologizacyjnych (np. jednostek leksykalnych połączonych cechą chronologizacyjną).

Główny mankament omawianych modeli leksykalno-derywacyjnych piszący te słowa widział w wadliwości komponentu chronologizacyjnego (wadliwość ta rozumiana była jako niedostatecznie silna teoria chronologizacyjna możliwa do zastosowania w roku opracowywania modelu). W skrócie, uwagi piszącego te słowa pod adresem tych modeli sprowadzają się m.in. do wskazania na:

a) niejasne (nieeksplicytne, nieudokumentowane teoretycznie) kryterium doboru materiału do bazy empirycznej modeli, tak w zakresie:

- chronologizacyjnym: nie ujawniono, zgodnie z jakim ciągiem dyrektyw chronologizowano materiał wyjściowy (domniemanie: przede wszystkim wykorzystując ówczesne, z lat 2001-2005, źródła dokumentacyjne T. Smółkowej contra źródła J. Wawrzyńczyka), jak i

- tematycznym, genologicznym, stylistycznym, testymonialnym, upowszechnieniowym, frekwencyjnym, geograficznym, prasoznawczym itp. (brak informacji co do wyboru prób kwotowych a losowych),

b) niejasne przesłanki skorelowania chronologizacyjnego punktu inicjalnego modelu opisowego roku 1985- (przez K. Waszakową) i roku 1989- (przez H. Jadacką) z główną racją wyboru tych granic dostępnym praktycznie materiałem w założeniu neonimicznym (pod red. D. Tekiel i T. Smółkowej), 
Piotr Wierzchoń: Na jakie pytania mógtby odpowiedzieć tworzony $w$ 2. dekadzie XXI $w$. model leksykalno-derywacyjny polszczyzny XX $w$.?

c) połączenie w obrębie jednego formantu derywacyjnego wielu kategorii nazw; np. Jadacka 2001 - -ówka; przy czym w modelu H. Jadackiej, podobnie jak w modelu np. E. Kwapień, nie zakładano odrębnych kwantytatywnie obserwacji kategorii: nazwy budynków, nazwy członkiń partii itp.; w modelu Waszakowa 2005 rozróżnia się: tele-I, II, III, euro-I, II itp., ale jest to jeszcze inny rodzaj rozróżnienia - bliskie homonimicznemu; inny problem, że K. Waszakowa wyróżnia np. 4 × super-, ale dla oznaczenia aktywności cząstki super- do strefy produktywności zlicza wszystkie 4 grupy derywatów jako elementy jednej monosemicznej kategorii super-, czyli bez rozróżnienia na 4 eksplikacje semantyczne, które opracowała (Waszakowa 2005: 127-128); jest to całkowicie zrozumiałe - gdyby w roku 2005 K. Waszakowa działała na osobnych kategoriach: super-1, super $_{-}$, super- ${ }_{3}$, super- ${ }_{-}$, czyli dla 4 różnych super-, o których wie, że istnieją, jak również dla każdych innych znaczeń wszelkich innych cząstek biorących udział w derywacji obcej końca wieku, np. w omawianym modelu dla $4 \times$ anty-, $2 \times e k s t r a-$ itd., to model taki byłby opracowywany po dziś dzień,

d) ujęcie w modelu H. Jadackiej (2001) kategorii -ość, -anie \{tu jest problem tego typu: czy te sufiksy, o ile w ogóle sufiksy derywacyjne [por. interesujące rozważania A. Matyki (2010) na bazie tekstu Chruścińskiej O formacjach potencjalnych $i$ okazjonalizmach], podpadają pod ogląd zorientowany na opis systemu słowotwórczego XX w.?\}; dla H. Jadackiej wzrost -ość po roku 1989 jest „bezdyskusyjny" (Jadacka 2001: 125); pojawia się pytanie, po uwzględnieniu 60\% różnicy w bazach empirycznych 1945-1964 i 1989-2000, czy zmiana z 6,28\% na 9,57\% jest zmianą „znaczną" (Jadacka 2001: 124); o tym, że w polskich modelach słowotwórczych występuje ewidentnie problem $\mathrm{z}$ metodologią uwzględniania lub nie formacji na -ość czy -anie i -enie, niech świadczy fakt, że w modelu 2. poł. XX w. w okresie 1945-1964 H. Jadacka notuje ok. 17,3\% udziału tych konstrukcji w zbiorze struktur sufiksalnych, a dla XIX w. E. Kwapień notuje 4,3\% udziału (rodzi się otwarte pytanie o możliwości takiego wzrostu przez okres jednego wieku),

e) ujęcie osobno przyrostków -anie i -enie (por. uwagi na ten temat H. Jadackiej i Z. Saloniego w wyjaśnieniach ujętych w: Dubisz, Gajda 2001: 87, 108).

f) niejasne (metaforyczne, trudne do odczytania i zinterpretowania) określenie globalnych tendencji derywacyjnych polszczyzny XX w. np. niejasna jest kategoria „tandetności” morfologicznej stosowana przez H. Jadacką (2001: 156),

g) podawanie morfemów o produktywności 1 (off-stownik), których wyróżnialność w obrębie danego modelu stoi pod znakiem zapytania, ponieważ w proporcji wyodrębniającej muszą być ujęte przynajmniej dwa indywidua; indywiduum numer $2 \mathrm{w}$ modelu Waszakowa 2005 było brane spoza modelu; w ujęciu Waszakowa 1994 również ujmuje się formanty o produktywności 1 , tj. wszelkie tzw. 
formanty jednostkowe, np. -isa, -ans itd.; dla porównania - E. Kwapień (2010) również wymienia wszystkie formanty jednostkowe (2010: 143), np. ze strefy IV (poniżej 10 derywatów); być może zadziałała tu substytucja lewostronna,

h) niepodawanie w ogóle tych morfemów (tendencja przeciwna) - najciekawszych odkryć słowotwórstwa diachronicznego 2. poł. XX w.; występuje tu też problem niejawności repertuaru strefy IV w Jadacka 2001 (afiksy te są ujęte w bazie empirycznej modelu H. Jadackiej, ale trzeba je wyodrębnić we własnym zakresie; dla lat powojennych elementy strefy IV podaje się jawnie),

i) niejasne określenie, co rozumie się przez zjawisko o stałej dynamice, a co przez zjawisko o randze dystynktywnej (wyróżniającej itp.) dla danego okresu; przykład: H. Jadacka mówi o dwu zjawiskach (Zjawiska stowotwórcze o stałej dynamice): tworzeniu skrótowców i derywatów od nich i o konstruowaniu derywatów odnazwiskowych; z kolei w Podsumowaniu fakt ten jawi się jako cecha wyróżniająca dla najnowszego systemu derywacyjnego (pojawia się tu jeszcze inny problem, gdyż H. Jadacka mówi, że i podstawy, i derywaty od nich stanowiły co najwyżej trzeciorzędny składnik opisu - co to jest „co najwyżej trzeciorzędny składnik opisu” - należy uściślić),

j) przejaskrawienie u H. Jadackiej sądów opisowo-wartościujących w rodzaju: lawinowy przyrost, nastawienie na automatyzmy itp.; dążność do automatyzmu jest podstawową własnością systemu morfologicznego (i każdego innego) języka naturalnego; na marginesie: H. Jadacka ma tu rację $\mathrm{w}$ zakresie oceny dynamiki kompozycji w 2. poł. XX w. - ale Jej sąd i tak jest przejaskrawiony, a jest to spowodowane dysproporcjonalnym przejęciem materiału nastawionego chyba na derywację lewostronną z Nowego stownictwa polskiego, słabo reprezentowaną w leksykografii polskiej); to, co cechuje model H. Jadackiej, to pewien (wyczuwalny) konflikt pomiędzy opisem warstwy ustabilizowanej (np. z uwzględnieniem norm skodyfikowanych) i warstwy uzusu (np. w zakresie materiału pobranego z Nowego słownictwa polskiego, dalekiego przecież od porządku kodyfikacji); Autorka wyróżna ponadto kategorię nominatywną i ekspresyjną neonimów; konflikt ten wyraża się w różnych uzasadnieniach przyjęcia lub nie danego typu materiału, tj. typu upowszechnionego (leksykografia ogólnopolska) i nieupowszechnionego (ekscerpcje pozaleksykograficzne),

k) niejasne kryteria uwzględnienia lub nie okazjonalizmów; możliwe tu są dwa wyjścia:

- nie uwzględnia się w opisie polszczyzny 2. poł. XX w. ewidentnych okazjonalizmów, gdyż traktuje się je jako efemerydy, byty nietrwałe,

- uwzględnia się okazjonalizmy, gdyż obrazują one potencję technik derywacyjnych, a zwłaszcza: produktywność danych morfemów. 
Piotr Wierzchoń: Na jakie pytania mógtby odpowiedzieć tworzony $w$ 2. dekadzie XXI $w$. model leksykalno-derywacyjny polszczyzny XX $w$.?

Silnie produktywny morfem jest tak produktywny, ponieważ jest dobrze (długo) osadzony w systemie. Jest tak osadzony, że generuje klasę okazjonalizmów. Te zaś, w związku z tym, że powstają, jeszcze mocniej ustalają strefę aktywności (I-IV) tego morfemu.

Piszący te słowa uważa, że i H. Jadacka, i K. Waszakowa zamierzały opisać system morfologiczny XX w. nieokazjonalistyczny (czyli jednostki nieefemeryczne, a więc zamierzały stworzyć model w rodzaju analiz materiału SStp. K. Kleszczowej lub M. Pastuch czy późniejszych - dla XIX w. E. Kwapień, w których to analizach ujmuje się zasób leksykograficzny), w każdym razie: tzw. zasób ogólnopolski. Przy czym raz te okazjonalizmy się „przydawały” w komponencie uzasadnień ewolucji systemu XX w., a raz - nie. Sprawiło to, że nie jest jasne stanowisko Badaczek wobec tych dwu rodzajów danych frekwencyjnych. Nie jest to, znowu, w tej chwili zarzut: w latach 2001-2005, tj. w latach przygotowywania modeli H. Jadackiej i K. Waszakowej, materiału empirycznego było mało... Badaczki analizowały te jednostki, które były możliwe do przebadania. Aby uniknąć tego typu połączenia danych, w niniejszym artykule proponuje się zbudowanie dwu oddzielnych modeli słowotwórczych:

- okazjonalistycznego (z jednostkami: elianada, gałczyńskiada itp.) i

- upowszechnieniowego (z jednostkami: cepeliada, familiada itp.),

l) kontrowersyjne szacunki dotyczące prognoz morfologicznych w zakresie niektórych morfemów, np. człon tele-I już w chwili formułowania wniosku przez K. Waszakową (2005: 178), tj. w połowie 1. dekady XXI w., był członem o zmniejszającej się dynamice tworzenia derywatów; podobnie przeszacowana jest prognoza dotycząca członu cyber- (generalnie rozdziały 3.1.3. monografii K. Waszakowej i III. 11. monografii H. Jadackiej stanowią zasób ważnych stanowisk predykcyjnych dot. systemu morfologicznego XXI w.),

l) niejasne sformułowania $\mathrm{w}$ warstwie opisowo-interpretacyjnej, w rodzaju:

- „techniki derywacyjne o zastosowaniu uniwersalnym” (Jadacka 2001: 156); co to jest zastosowanie uniwersalne techniki derywacyjnej? czy to jest to samo, co K. Kleszczowa nazywa, również chyba metaforycznie, „przełamywaniem barier części mowy”? Ale wówczas własność, którą zauważa H. Jadacka jako dystynktywną dla 2. poł. XX w., była własnością systemu derywacyjnego nie od 2. poł. XX w.; H. Jadacka miała najprawdopodobniej na uwadze pojawienie się nowych morfemów konkatenujących, ale tu powstaje jeszcze inny problem, ponieważ morfemy te, np. pseudo-, super-, dez- itd., konkatenowały tzw. uniwersalnie (z różnymi kategoriami części mowy) przed rokiem 1939, co można sprawdzić w rejestrach fotodokumentacyjnych,

- „W najnowszym systemie jest więcej (...) typów struktur nieograniczenie produktywnych” (Jadacka 2001: 155-156). Co to są „typy struktur"? Czy ma to związek z kompozycją? 
- „Sprawność komunikatywna nowych struktur [wszystkich tego typu w całej historii polszczyzny - P.W.] jest w pewnym stopniu [w jakim? - P.W.; jak określamy te stopnie?] gwarantowana przez wyrazistość [por. ang. transparency vs. opacity; D. Buttler stosuje w swoich pracach np. pojęcie przejrzystości] semantyczną struktur prefiksalnych, formacji z prefiksoidami, derywatów (...)"; jaka jest różnica definicyjna pojęć: struktura, formacja, derywat, typ?

- „sensowne wyrównanie proporcji między derywatami” (Jadacka 2001: 152) przejętymi w wyniku tzw. fascynacji europejskością, np. -ing, -ent, a rodzimymi: -acz, -owiec itd.; co kryterialnie (jaki udział liczbowo-proporcjonalny) przesądza o „sensowności wyrównania"?

\section{Dlaczego warto podjąć próbę tworzenia modelu polszczyzny XX w.? Skala deficytów opisów pol- szczyzny XX w. a możliwości 2. dekady XXI w.}

Ocena każdego modelu możliwa jest jedynie po uwzględnieniu czasu (daty) jego budowy. Poniżej wyliczy się cechy omawianych modeli, które z dzisiejszego (ale nie ze względu na czas powstawania modelu) punktu widzenia można by było interpretować jako deficyty:

a) przebadano relatywnie mało materiału, tj. każdorazowo kilka tysięcy derywatów (obecnie można przebadać większą liczbę obiektów językowych, a umożliwia to $\boldsymbol{T L C H}$,

b) nie przebadano systemu derywacyjnego 1. poł. XX w. w perspektywie ewolucyjnej (np. w odniesieniu do badań dot. 2. poł. XX w.),

c) materiał 2. poł. XX w. przebadano w skokach chronologizacyjnych w rodzaju 1945-1964 i 1989-2000 (było to maksimum wówczas osiągalne); obecnie można ustalać projekt o skoku corocznym: 1901, 1902, 1903, 1904, 1905... 1995, 1996, 1997, 1998, 1999, 2000; model taki ukazywałby płynnie tendencje diachroniczne XX w.,

d) nie przebadano materiału ze względu na informacje dotyczące lokalizacji jednostek leksykalnych w tekście i lokalizacji geograficznej derywatów (dopiero uwzględnienie tego drugiego parametru pozwoli w ramach teorii arealnej określić cechę ogólnopolskości derywatu; dotąd zasoby materiałowe pozwalały jedynie na formułowanie zapewnień o tej własności),

e) dyskutowane modele polszczyzny XX w. nie mogły, z obiektywnych względów, odwołać się do informacji frekwencyjnej (a zatem pojęcie przyswojenia, upowszechnienia derywatu analizowanego w wielkim modelu także miało znamiona zapewnienia); obecnie, dzięki $\boldsymbol{T L C H}$, dysponujemy już pierwszymi danymi dotyczącymi frekwencji tekstowej poszczególnych derywatów w obrębie całego XX w., w tym 1. poł. XX w. (por. dalej wykresy frekwencyjne dla przykładowego okresu 1920-1939), 
Piotr Wierzchoń: Na jakie pytania mógtby odpowiedzieć tworzony $w$ 2. dekadzie XXI $w$. model leksykalno-derywacyjny polszczyzny XX $w$.?

f) $\mathrm{w}$ dotychczasowych modelach $\mathrm{w}$ warstwie strukturalnej analizy formalno-znaczeniowej uwzględniono dwa parametry - chronologizacyjny i derywacyjny, tj. w zakresie techniki derywacyjnej:

- w skoku chronologizacyjnym, np. w modelu H. Jadackiej (2001) dwukrotnym: 1945-1964 i 1989-2000,

- w skoku chronologizacyjny, np. w modelu T. Smółkowej (1976) jednokrotnym: względem roku 1945,

g) materiał, który przebadano $\mathrm{w}$ dotychczasowych modelach $\mathrm{XX}$ w. (1969-2010), został mocno zredatowany; np. piszący te słowa przebadał testowo jednostki leksykalne rozpoczynające się na literę $d$ z modelu H. Jadackiej (2001: 173-174); aplikacja TLCH pozwoliła na redatację ok. 50\% materiału,

h) w literaturze przedmiotu zawarto informacje o koncepcji opracowania Suplementu do Słownika warszawskiego (por. np. Wawrzyńczyk 1999, Majdak 2008: 29, 31, 230), które wskazują na realne istnienie istotnego kwantytatywnie zbioru jednostek leksykalnych z chronologizacją do roku 1939.

Dodatkowo, niektóre konkluzje, jakie zawarte są w komponencie interpretacyjnym wielkich modeli derywacyjnych 2. poł. XX w., nie przekonują piszącego te słowa. Przykład: T. Smółkowa (1976: 106) uznaje, że powojennie liczba nazw przedmiotów jest prawie równa liczbie nazw osób i liczbie nazw pojęć (i że po II wojnie światowej „pojawiło się bardzo wiele nowych przedmiotów"). Autorka uzasadnia to pojawienie się koniecznością odbudowy (odbudowy dosłownej) zrujnowanej Polski, co preferuje pewną „konkretność" obsługi przez system derywacyjny: powstają głównie nazwy przedmiotów, np. narzędzi. Piszący te słowa uważa mimo wszystko, że:

a) trudno obronić sąd, że lokutor polski w okresie 1945-1969 interesował się głównie cegta i betoniarnia, a nie interesował się (i nie wyrażał tego zainteresowania w języku) życiem duchowym, rozwojem kulturalnym, intelektualnym itp.,

b) sąd ten wynika z dysproporcjonalnego doboru materiału w SJPD, który służył do konstrukcji modelu Smółkowa 1976 i Smółkowa, Tekiel 1977, tak w zakresie:

- chronologizacyjnym (np. czyszczarka jest neonimem przedwojennym, a nie, jak się mylnie uznaje, powojennym; betoniarnia - również; teksty przedwojenne notują setki potwierdzeń tego derywatu; dodatkowo pojawia się tu problem tzw. leksykologiczny, tj. kiedy, w jakim procesie homonimizacji, czyli jak datowanym i o jakiej różnicy semowej, derywat z SJPD staje się derywatem z Suplementu SJPD, który został uwzględniony w Smółkowa 1976: 116; Klasyfikacja zawodu obiektowego, przyjęta w celu opracowania Drugiego 
powszechnego spisu ludności z początku lat 30., wyróżnia już, równolegle, i cementownie, i betoniarnie; oznaczałoby to, że również cementownie, ze względu na rozwój powojennej linii technologicznej, winny uzyskać nową, uaktualnioną definicję z kwalifikatorem techn w Suplemencie SJPD; tak się jednak nie stało - dlaczego? co szczególnego projektowo i w konsekwencji leksykologicznie odróżnia polską betoniarnię z lat 6o., znanej przedwojennie, od polskiej cementowni z lat 60., znaną przedwojennie, tak aby jedynie betoniarnię uznać za neonim powojenny - Smółkowa 1976: 116?; desygnatów tych nie odróżnia pod względem dynamiki rozwoju nic, a zatem brak tu różnicy semantycznej na poziomie eksplikacji dynamiki rozwoju tych przedsiębiorstw; po dokonaniu rekonstrukcji teorii T. Smółkowej z roku 1976 można uznać, że problem tkwi po prostu w tym, iż w modelu Smółkowa 1976 wykorzystano mechaniczną dyrektywę, sprowadzającą się do uznania za neonim powojenny tych wszystkich jednostek, które notowane były w Suplemencie do SJPD), jak i

- derywacyjnym (brakuje wielu derywatów na -ość, -anie, grupy formacji prefiksalnych: kontr-, pseudo-, anty-, ponad-, przed-itd.).

Czyszczarkę T. Smółkowa (1976: 119) traktuje jako neonim powojenny, powstały po 1945 roku, ponieważ, zgodnie z zastosowanym przez Autorkę prawem neonimicznym (kryterium leksykograficzne), czyszczarka nie ma potwierdzenia przedwojennego w SJPD. Na marginesie, hasło SJPD odsyła z hasła czyszczarka, w artykule którego nie ma żadnego poświadczenia ilustracyjnego (egzemplum - w ujęciu np. E. Rudnickiej z roku 2010), do hasła oczyszczarka. Niestety, w haśle oczyszczarka nie znajduje się tekstowe poświadczenie hasła czyszczarka. Czyszczarka nie jest więc neonimem powojennym, ponieważ notowana jest w tekstach przedwojennych, na co np. zwrócił uwagę J. Wawrzyńczyk, a na co z kolei zwróciła uwagę H. Jadacka (2001: 21), podobnie zresztą jak w wypadku jednostki leksykalnej betoniarnia (dotąd jednak w literaturze przedmiotu nie pojawił się nakaz przywrócenia chronologizacyjnego betoniarni do modelu Jadacka 2001; tzn. nie wskazuje się, co odbywa się każdorazowo w odniesieniu do rzekomo mylnych redatacji piszącego te słowa, że betoniarnia - słusznie usunięta z bazy empirycznej modelu Jadacka 2001 - jest inną leksykologicznie betoniarnia niż w modelu Smółkowa 1976, co powoduje, że betoniarnia z modelu T. Smółkowej musi powrócić do modelu H. Jadackiej, ponieważ w przykładzie T. Smółkowej mamy do czynienia z zupełnie innym typem przedsiębiorstwa, a więc typem neosemantycznym, np. ze względu na liczbę zatrudnionych tam pracowników, co automatycznie powoduje homonimizację nowej, neonimicznej powojennie chronologizacji betoniarni).

Na marginesie: byłoby cenne poznawczo przygotować rozprawę na temat wyłącznie jednego ciągu diakrytów z modelu H. Jadackiej (2001: 47), a mianowicie dziewiarka, np.: Lingwochronologizacyjna komiwojażerka dziewiarki po wielkich modelach polszczyzny $X X w$. Próba rekonstrukcji 
Piotr Wierzchoń: Na jakie pytania mógtby odpowiedzieć tworzony $w$ 2. dekadzie XXI $w$. model leksykalno-derywacyjny polszczyzny XX $w$.?

metodologii kolekcji bazy empirycznej. Oto, w skrócie, prawdopodobny przebieg wydarzeń: H. Jadacka pobrała ten derywat z modelu H. Satkiewicz z roku 1969, traktowany tamże jako neonimiczny względem roku 1945, ale nie uwzględniła, a powinna, jego nieobecności w roku 1976 w modelu T. Smółkowej, co by wskazywało na to, że dziewiarka jest derywatem przedwojennym, ale, co dodatkowo istotne, dziewiarka w SJPD ma dwa znaczenia: 'nazwa wykonawcy zawodu' i 'urządzenie'; H. Jadacka przyjmuje do swojego modelu wyłącznie znaczenie 'nazwa wykonawcy zawodu' i zlicza dziewiarkę do grupy nazw żeńskich, do 44 formacji, co daje w Jej modelu 63,77\% na -ka; dlaczego jednak do modelu H. Jadackiej nie weszła dziewiarka 'urządzenie' - nie jest jasne; ale, co istotne, w ostateczności rozwiązanie H. Jadackiej jest, w świetle danych lingwochronologizacyjnych piszącego te słowa, trafne - maszyny dziewiarki były obecne w polskim przemyśle do roku 1939, a kobiety dziewiarki - nie; ale i tu pojawia się istotny problem, ponieważ Stownik nazw pracowników $w$ przemyśle i rzemiośle z roku 1939 pod red. Antoniego Romana notuje dziewiarza, który zresztą niesłusznie jest uznany, znowu w źródle Smółkowa 1976, za neonim powojenny, a zatem, gdyby przyjąc hipotetyczne kryterium lingwochronologizacyjne K. Waszakowej (2005: 46), ujęte pod nazwą „lingwochronologizacyjne uzupełnianie gniazda derywacyjnego" - wówczas dziewiarkę 'nazwa wykonawcy zawodu' należałoby usunąć $\mathrm{z}$ modelu H. Jadackiej.

Rozważania powyższe stanowią ilustrację wniosku, do jakiego doszedł piszący te słowa. W językoznawstwie polskim w zakresie konstrukcji wielkich modeli praktycznie nie występuje problem analizy słowotwórczej (kontrowersje, wywołane m.in. ujęciem I. Kaproń-Charzyńskiej, dotyczą w pewnym zakresie technik derywacyjnych: paradygmatycznej i ujemnej; w mniejszym stopniu kontrowersje dotyczą kwestii segmentacyjnych, tj. miejsc granic morfologicznych), natomiast istnieje bardzo poważny problem komponentu lingwochronologizacyjnego (przez określenie „bardzo poważny problem" rozumie się tu np. kilkudziesięcioprocentową omyłkę lingwochronologizacyjną w zakresie omawianych modeli). Przykładowo, nie istnieje problem z morfonologiczną i słowotwórczą analizą składnikową derywatu trapeź-ista (Jadacka 2001: 83), ale jest problem z jego analizą lingwochronologizacyjną (nie jest to neonim powstały po roku 1989, jak datuje neonimicznie H. Jadacka, tylko przedwojenny; tu dochodzi do jeszcze bardziej zagadkowej konfiguracji: derywat ten znajduje się w źródle Smółkowa 1976 na s. 159; dlaczego zatem pojawia się on w modelu H. Jadackiej jako powstały po roku 1989 - nie jest jasne, skoro materiał z modelu Smółkowa 1976 był w modelu H. Jadackiej uwzględniony, ale w submodelu 1945-1964, a zatem trapezista nie może należeć jednocześnie do dwu rozłącznych względem okresu 1965-1988 zbiorów, ponieważ nie mógł powstać neonimicznie dwukrotnie, a tzw. ponowna nominacja czy neosemantyzacja nie wchodzi tu w grę). Polska szkoła derywatologiczna (osobno: śląska, np. w osobach M. Honowskiej czy K. Kleszczowej i Jej Zespołu, i warszawska, w wiadomych osobach, czy też krakowska - M. Skarżyńskiego) zasłużenie osiągnęła szczyt swojego rozwoju, wypracowała (i efektyw- 
nie przetestowała w postaci licznych opracowań szczegółowych: teoretycznych i leksykograficznych) metodologię opisu derywatu polskiego, tak na sposób binarny, jak i gniazdowy, natomiast polska szkoła lingwochronologizacyjna, reprezentowana w wielu bezkrytycznych odwołaniach, głównie do prac T. Smółkowej, wymaga refleksji metodologicznej. Refleksja wymaga $\mathrm{z}$ kolei uporządkowania pojęciowego, operacyjnego itp. istniejących programów lingwochronologizacyjnych. W roku 2008 pojawia się konieczność opracowania gramatyki chronologizacyjnej, która umożliwiłaby w uporządkowany, metodologiczny sposób mówienie o różnych programach lingwochronologizacyjnych.

Suma obserwacji polskich teorii lingwochronologizacyjnych ufundowała dodatkowy przedmiot namysłu: metalingwochronologizację. Lingwochronologizacja odpowiada na pytanie co i jak chronologizować. Metalingwochronologizacja (czyli niejako: historia lingwochronologizacji) odpowiada na pytanie: co i jak chronologizowano w poszczególnych programach lingwochronologizacyjnych. Metametalingwochronologizacja (do tego stopnia polska myśl chronologizacyjna jeszcze nie doszła w sposób wykrystalizowany, tj. w formie teorii; odbywa się to jedynie na poziomie recenzji prac metalingwochronologizacyjnych piszącego te słowa) odpowiada natomiast na pytania: jak opisywano i oceniano to, co i jak chronologizowano $\mathrm{w}$ poszczególnych programach lingwochronologizacyjnych. Innymi słowy, metametalingwochronologizacja ocenia zbiorczo oceny konkretnych programów lingwochronologizacyjnych, czyli ocenia metalingwochronologizację.

Przykładowo, programem lingwochronologizacyjnym jest program np. T. Smółkowej z roku 1998 i J. Wawrzyńczyka z roku 2000 (Słownik bibliograficzny języka polskiego). Wypowiedzią metalingwochronologizacyjną względem Smółkowa 1998 i Wawrzyńczyk 2000 jest np. Wierzchoń 2010. Wypowiedzią metametalingwochronologizacyjną jest z kolei ewentualna ocena Wierzchoń 2010, czyli:

\begin{tabular}{|l|l|}
\hline \multicolumn{1}{|c|}{ Typ refleksji } & \multicolumn{1}{c|}{ Realizacja } \\
\hline lingwochronologizacja & $\begin{array}{l}\text { Tekiel 1988, Smółkowa 1998, Waw- } \\
\text { rzyńczyk 2000 itp. }\end{array}$ \\
\hline metalingwochronologizcja & $\begin{array}{l}\text { Wierzchoń 2010, Nowakowska } \\
\text { 2005, przypis 21. }\end{array}$ \\
\hline metametalingwochronologizcja & $\begin{array}{l}\text { ocena, np. w formie recenzji: } \\
\text { Wierzchoń 2010 (w porównaniu, o } \\
\text { ile istnieje, do innej wypowiedzi } \\
\text { metalingwochronologizacyjnej) }\end{array}$ \\
\hline
\end{tabular}

Tabela 2. Stopnie dociekań lingwochronologizacyjnych 
Piotr Wierzchoń: Na jakie pytania mógtby odpowiedzieć tworzony $w$ 2. dekadzie XXI $w$. model leksykalno-derywacyjny polszczyzny XX $w$.?

\section{Teoria lingwochronologizacyjna (TLCH) jako punkt wyjścia modelu polszczyzny XX w. (pro- blem konstrukcji bazy empirycznej)}

W językoznawstwie rodzaju tu propagowanego idzie o:

a) opis (pokategoryzowanie i przeliczenie mocy kategorii) danej rzeczywistości (np. rzeczywistości leksykalnej XX w.) ze względu na zmienne istotne dla opisu przestrzeni badawczej, czyli ze względu na cechy parametrów uznanych za istotne dla prowadzonego badania,

b) interpretację tego, co ujawnia ten opis kategorialny,

c) w ujęciach diachronicznych, np. Jadacka (2001) czy Waszakowa (2005) - ewentualnie sformułowanie prognoz (ekstrapolacja) dotyczących stanu rzeczywistości w przyszłości.

Opis rzeczywistości ujmuje wyłącznie to, co ujmują (datum questionis) pytania, jakie badacz zamierza postawić pod adresem badanej rzeczywistości. Żaden model nie odpowie na jakiekolwiek pytanie, które uprzednio nie zostanie zadane materiałowi (por. Such 1975: 29; por. także Kozielecki 1992, Nęcka 1994). To, co tu się nazywa pytaniami względem danego materiału, to po prostu pytania o obiekty materiału ze względu na dane parametry teorii. I tak, przykładowo, H. Jadacka (2001) zadaje pytania:

a) w jaki sposób efektywnie zgromadzić materiał badawczy służący jako podstawa do konstrukcji modelu słowotwórczego 2. poł. XX w., tzn. jak opisać parametry tej ekscerpcji,

b) jak podzielić okres 2. poł. XX w. (na jakie podokresy), aby efektywnie opisać ewolucję systemu słowotwórczego 1945-2000,

c) jaki jest inwentarz formantów słowotwórczych dla okresów 1945-1964 i 1989-2000 dla 3 części mowy,

d) do jakiej strefy aktywności należy dany formant (uprzednio: dla jakiego przedziału produktywności ograniczać strefy aktywności, np. ponad 6o derywatów, 31-60, 6-30, poniżej 5, a dla formacji po roku 1989 poniżej 6 derywatów),

e) które kategorie części mowy należy wybrać do modelu, aby efektywnie przeprowadzić opis derywacyjny polszczyzny 2. poł. XX w.,

f) w jaki sposób pogrupować derywaty ze względu na parametr techniki derywacji, aby efektywnie przeprowadzić opis derywacyjny polszczyzny 2. poł. XX w.,

g) itd.

TLCH odpowiada na inne pytania. Jako teoria językoznawstwa stosowanego odpowiada m.in. na pytania:

a) w jaki wykonalny i najefektywniejszy sposób w roku 2008 ustalić dane chronologizacyjne dla polszczyzny XX w., 
b) w jaki wykonalny i najefektywniejszy sposób w roku 2008 prezentować graficznie te dane (fotodokumentacja),

c) w jaki wykonalny i najefektywniejszy sposób wykorzystać wszystkie parametry tekstologiczne (np. miejsce wydania, strona tekstu, objętość tekstu, periodyczność itd.), ujęte w zdigitalizowanych tekstach,

d) co jest przyczyną pojawienia się tak wielu omyłek chronologizacyjnych w modelach współczesnej polszczyzny,

e) oraz najważniejsze: z jaką siłą można postawić daną hipotezę neonimiczną względem danej granicy datacji w obrębie XX w. (siła ta uzależniona jest od liczby wykonanych dyrektyw ekscerpcyjno-chronologizacyjnych); to, co A. Bańkowski nazywa w Etymologicznym słowniku języka polskiego: możliwe, prawdopodobne itd., w $\boldsymbol{T L C H}$ nazywa się, przykładowo:

- dla chronologizacji x jednostki zastosowano: $\boldsymbol{D}_{1}, \boldsymbol{D}_{4}, \boldsymbol{D}_{5}, \boldsymbol{D}_{22}, \boldsymbol{D}_{27} \ldots$

- dla chronologizacji x jednostki zastosowano: $\boldsymbol{D}_{12}, \boldsymbol{D}_{14}, \boldsymbol{D}_{23}, \boldsymbol{D}_{24}, \boldsymbol{D}_{27 \ldots}$

- dla chronologizacji x jednostki ${ }_{3}$ zastosowano: $\boldsymbol{D}_{3}, \boldsymbol{D}_{4}, \boldsymbol{D}_{5}, \boldsymbol{D}_{22} \ldots$

- dla chronologizacji x jednostki ${ }_{4}$ zastosowano: $\boldsymbol{D}_{8}, \boldsymbol{D}_{9}, \boldsymbol{D}_{15}, \boldsymbol{D}_{22}, \boldsymbol{D}_{23} \ldots$

- dla chronologizacji x jednostki ${ }_{5}$ zastosowano: $\boldsymbol{D}_{1}, \boldsymbol{D}_{19} \ldots$

- dla chronologizacji x jednostki6 zastosowano: $\boldsymbol{D}_{2}, \boldsymbol{D}_{4}, \boldsymbol{D}_{14}, \boldsymbol{D}_{26}, \boldsymbol{D}_{28} \ldots$

- dla chronologizacji x jednostki ${ }_{100}$ ooo zastosowano: $\boldsymbol{D}_{2}, \boldsymbol{D}_{11}, \boldsymbol{D}_{23}, \boldsymbol{D}_{29} \ldots$

- itd.

Generalnie: i H. Jadackiej i K. Waszakowej, i P. Wierzchoniowi, i J. Wawrzyńczykowi, i T. Smółkowej chodzi o to samo - o poznanie zasobu jednostek chronologizowanych względem danej granicy datacji. Ta granica wynika z granicy czasowej modelu, który zamierza się tworzyć względem danego roku kalendarzowego, np. w polskiej neonimice są to m.in.: 1945, 1985, 1989 itp. Dyrektywa neonimiczna względem roku 1989 H. Jadackiej (2001) przedstawiała się (w pewnym uproszczeniu) tak:

$$
\begin{gathered}
\boldsymbol{D}_{1}=\text { przyjmij zbiór Smółkowa 1998, } 1999 \\
\text { i odejmij: Wawrzyńczyk 1994, } 1999 .
\end{gathered}
$$

Z kolei dyrektywa neonimiczna w teorii Smółkowa 1998, 1999 przedstawiała się tak: sprawdź, czy danego hasła nie ujmuje się w Stowniku języka polskiego pod red. W. Doroszewskiego lub M. Szymczaka. Jeżeli w tych słownikach nie ujmuje się np. derywatu pozasądowy (Smółkowa 1999: 65, Jadacka 2001: 190), to jest to neonim powojenny (ale pozasądowy jest licznie obecny $\mathrm{w}$ tekstach $\mathrm{z}$ 1. poł. XX w. - nie jest to więc w świetle danych z przyrody neonim względem roku 1945).

A zatem w jakim celu ustanowiono $\boldsymbol{T L C H}$ i jaki ma ona związek z modelem polszczyzny XX w.? TLCH sformułowano m.in. po to, aby móc określić, z jaką siłą dyrektywalną uzyskało się daną chronologizację? A ta siła dyrektywalna to po prostu siła postawienia hipotezy neonimicznej. Obecnie (2. dekada XXI w.) można podjąć próbę strukturalnego umetrycz- 
Piotr Wierzchoń: Na jakie pytania mógtby odpowiedzieć tworzony $w$ 2. dekadzie XXI $w$. model leksykalno-derywacyjny polszczyzny XX $w$.?

nienia owej sily. To umetrycznienie to wyliczenie mocy (= liczba kardynalna) zbioru zastosowanych dyrektyw zaangażowanych w wyprowadzenie danej chronologizacji, czyli:

- dla chronologizacji x jednostki zastosowano: $\boldsymbol{D}_{1}, \boldsymbol{D}_{4}, \boldsymbol{D}_{5}, \boldsymbol{D}_{22}, \boldsymbol{D}_{27} \ldots$

Osobne stanowisko metodologiczne - na bazie koncepcji zbiorów rozmytych w teorii L. A. Zadeha - piszący te słowa właśnie opracowuje.

\section{Uzasadnienie celu podjęcia pracy}

Celem pracy zmierzającej do budowy modelu leksykalno-derywacyjnego jest poznanie polszczyzny XX w. ze względu na wszystkie parametry językowe, których zasadność stwierdza się na wstępnym, preteoretycznym etapie badań. Model polszczyzny XX w. musi w dużej mierze uwzględnić cenne parametry wypracowane w teoriach Jadacka 2001 czy Waszakowa 2005 (np. parametr podziału techniki derywacji na derywację afiksalną i bezafiksalną, parametr segmentacyjny podziału na morfemy itp.). Parametry te wzmocni poniższa propozycja piszącego te słowa, wynikająca z analizy tekstu polskiego XX w. w odmianie totalnej, tj. takiej, która fundowana jest przez $\boldsymbol{T L C H}$, w zakresie np.:

a) pisowni łącznej lub rozdzielnej członów wchodzących w derywację,

b) pisowni obcej lub zasymilowanej (w zakresie zapożyczeń),

c) pisowni cudzysłowowej lub nie (operatory testymonialności),

d) obserwacji jednostek leksykalnych w parametrach genologicznych, prasoznawczych, frekwencyjnych,

e) itp.

Efekt tego poznania dzieli się na dwie kategorie:

a) silna (ze względu na masę materiału, a stąd - stopień prawdopodobieństwa) konfirmacja lub falsyfikacja hipotez pochodzących z wielkich modeli typu Jadacka 2001 czy Waszakowa 2005 (jeden i drugi wynik, którego dziś jeszcze nie znamy, byłby korzystny poznawczo),

b) poznanie tej klasy odpowiedzi na takie pytania, które w modelach tych (tego typu) nie zostały zadane, np. które formanty konkatenują najczęściej z jaką częścią mowy w jakim przedziale 1901-2000.

Niektóre sformułowane poniżej pytania na pewno będą się pokrywały z pytaniami modelu np. Satkiewicz 1969 czy Jadacka 2001. H. Jadacka stawia, przykładowo, pytanie: jakie są produktywne przyrostki przymiotnikowe po roku 1989? I, przeprowadzając badania, polegające na analizie derywacyjnej, zasadzającej się na dokonaniu podziału formy kanonicznej jednostki leksykalnej na temat oraz przyrostek, prowadzącej do dychotomizacji derywatu, uzyskuje odpowiedź: -owy, -ski, -ny, -alny itd. Nowy model może zapytać o te przyrostki po roku 1901, 1902, 1903 itd. Nowy model może również zapytać o te przyrostki po roku 1901, 1902, 1903 itd. 
biorąc pod uwgę typ periodyku (dziennik - teksty „łatwiejsze”, rocznik „teksty trudniejsze”) czy temat czasopisma (chirurgia, łowiectwo, radioelektronika, militaria, moda, film itd.). W wypadku przyrostków przymiotnikowych wielkich różnic ze względu na typ tekstu raczej nie będzie. Ale w wypadku przyrostków rzeczownikowych - różnic można się spodziewać.

W proponowanym ujęciu okres 1901-2000 jest podzielony na wszystkie możliwe podokresy, tj.:

\begin{tabular}{|c|c|c|c|c|c|c|c|c|}
\hline 1 & 1901 & 1902 & 1903 & 1904 & 1905 & 1906 & (...) & Przedzial \\
\hline $\mathbf{C}_{1}$ & - - & & & & & & & 1901 \\
\hline $\mathbf{C}_{2}$ & - & - & & & & & & 1901-1902 \\
\hline $\mathbf{C}_{3}$ & -- & -- & -- & & & & & 1901-1903 \\
\hline $\mathbf{C}_{4}$ & -- & -- & -- & -- & & & & 1901-1904 \\
\hline $\mathbf{C}_{5}$ & -- & -- & -- & -- & -- & & & 1901-1905 \\
\hline$(\ldots)$ & & & & & & & & (...) \\
\hline $\mathbf{C}_{6}$ & & -- & & & & & & 1902 \\
\hline $\mathbf{C}_{7}$ & & -- & -- & & & & & 1902-1903 \\
\hline $\mathbf{C}_{8}$ & & -- & -- & -- & & & & 1902-1904 \\
\hline $\mathbf{C}_{9}$ & & -- & -- & -- & -- & & & 1902-1905 \\
\hline $\mathbf{C}_{10}$ & & -- & - & -- & -- & -- & & 1902-1906 \\
\hline
\end{tabular}

Tabela 3. Podział okesu 19o1-2ooo na wszystkie możliwe ciagte podokresy (przedziaty)

Tak podzielony okres XX w., tj. podzielony na rodzinę $\mathbf{C}$, czyli zbiór wszystkich uporządkowanych (kontynualnych, bez przerwy czasowej) zbiorów lat XX w. $\left(\mathbf{C}_{1}, \mathbf{C}_{2}, \mathbf{C}_{\mathrm{n}}\right)$, pozwoli przebadać system polszczyzny z dokładnością coroczną. W ten sposób uzyskuje się np.:

a) 100 zbiorów jednorocznych (lata: 1901, 1902, 1903 itd. do 2000),

b) 50 zbiorów dwuletnich (okres: 1901-1902, 1902-1903, 1903-1904 itd. do 1999-2000),

c) 1 zbiór stuletni (1901-2000).

Porównanie składu leksykalnego wszystkich zbiorów (C) prowadzi do uzyskania obrazu ewolucji polszczyzny XX w.

W konsekwencji oczekiwany model polszczyzny XX w. odpowie między innymi na pytania o wielkość i skład podzbiorów jednostek języka charakteryzowanych ze względu na:

a) przedzial czasu $(\mathbf{C})$,

b) tematyczny typ tekstu (t),

c) geografię występowania (g),

d) wartość parametru prasoznawczego:

- periodyczność (p),

- lokalizacja topologiczna (1), 
Piotr Wierzchoń: Na jakie pytania mógtby odpowiedzieć tworzony $w$ 2. dekadzie XXI $w$. model leksykalno-derywacyjny polszczyzny XX $w$.?

np.:

$\mathbf{t}$ = sztuka (t1), myślistwo (t2), akwarystyka (t3), religia (t4), astronomia (t5) itp.,

g = Warszawa (g1), Poznań (g2), Inowrocław (g3) itp.,

$\mathbf{p}=$ dziennik (p1), tygodnik (p2), miesięcznik (p3), rocznik (p4) itp.,

$\mathbf{l}=$ pierwsza strona (l1), druga strona (l2), trzecia strona (l3) itp.,

oraz ze względu na parametry (segmentacyjne, ortograficzne, onomastyczne, pochodnościowe, morfonotaktyczne, leksykologiczne, socjolingwistyczne, składniowe, kategorii nazw, kategorii części mowy itp.) ujęte w poniższych pytaniach, czyli...

\section{Pytania rozstrzygnięcia i pytania dopelnienia}

Q1.

Jaki jest inwentarz morfemów słowotwórczych polszczyzny w $\mathbf{C}$ ze względu na $\mathbf{t}, \mathbf{g}, \mathbf{p}, \mathbf{l}$ i które morfemy należą do której strefy aktywności?

Komentarz 1: cel - osiągnięcie najobszerniejszego rejestru w historii językoznawstwa polskiego oraz wyznaczenie rodziny wszystkich możliwych podzbiorów wyznaczanych strefą aktywności morfemów ze względu na wszystkie możliwe przedziały okresu 1901-2000 oraz rodzinę zbiorów: $\mathbf{t}, \mathbf{g}, \mathbf{p}, \mathbf{l}$.

Komentarz 2: hipoteza - złożenia wykorzystujące w swojej strukturze tzw. formalnej człony słownictwa specjalistycznego przechodzą do trwałego zasobu leksykalnego poprzez ostatnie strony gazet.

Q2.

W którym przedziale z 1901-2000, tj. w którym C nastąpił największy i najmniejszy przyrost formacji o danym afiksie ze względu na t, $\mathbf{g}, \mathbf{p}, \mathbf{l}$ ?

Komentarz: na przykład, na co wskazuje w swoich badaniach dla okresu 1985-2004 K. Waszakowa (2005: 143), w połowie 1. dekady XXI w. wzrasta liczba konstrukcji z euro-II, co ma związek z przystąpieniem Polski do $\mathrm{UE}$; jest to sąd racjonalny; $\mathrm{z}$ drugiej strony - np. sześćdziesięciodwukrotny wzrost liczby derywatów z eks- w latach 1985-2004 w stosunku do lat 70. (Waszakowa 2005: 176) nie wydaje się prawdopodobny.

Q3.

Jakie są zbiory wariantów tych morfemów (np. -acja dla -ja) ze względu na $\mathbf{t}, \mathbf{g}, \mathbf{p}, \mathbf{l} \mathrm{w} \mathbf{C}$ ?

Komentarz: jaki jest procentowy udział wariantów w danych formantach? Od czego (fonotaktycznie) zależą te ograniczenia?

Q4.

W jakim C notuje się maksimum ilościowej zmiany tego inwentarza w $\mathbf{t}, \mathbf{g}$, p, 1 ?

Komentarz: jaka jest interpretacja tego stanu? 
Q5.

Jaki jest udział w $\mathbf{C}$ derywatów lewostronnych zapisywanych z łącznikiem $\mathrm{wt}, \mathbf{g}, \mathbf{p}, \mathbf{l}$ ?

Komentarz: dla całego słowotwórstwa lewostronnego XX w., głównie obcego, pisownia z łącznikiem jest kwestią fundamentalną i parametr ten musi być przyjęty jako bezwyjątkowy - np. notowana jako neonim powojenny autodrezyna znana jest tekstom przedwojennym jako auto-drezyna, natomiast neokapitalista, szacowany jako neonim po roku 1985 (Waszakowa 2005: 246), notowany jest w postaci neo-kapitalista w "Gazecie Bankowej" z $1931 \mathrm{r}$.

Q6.

Jaki jest udział w $\mathbf{C}$ derywatów bezafiksalnych w t, $\mathbf{g}, \mathbf{p}, \mathbf{l}$ ?

Komentarz: hipoteza - derywaty paradygmatyczne i ujemne przechodzą do trwałego zasobu leksykalnego poprzez ostatnie strony czasopism ze względu na niektóre t i p.

Q7.

Jaka jest zależność między długością wyrazu a liczbą derywatów, które są tworzone na jego podstawie oraz czasem, jaki upływa do chwili osiągnięcia wielkości $w$ gniazda derywacyjnego ze względu na $\mathbf{t ,}, \mathbf{g}, \mathbf{p}, \mathbf{l}$ ?

Q8.

Jaki jest stosunek liczby nazw własnych (np. nazw firm) do nazw pospolitych o tym samym afiksie ze względu na $\mathbf{t}, \mathbf{g}, \mathbf{p}, \mathbf{l}$ w $\mathbf{C}$ ?

Komentarz: jaka jest proporcja nazw (np. biznesowych) do derywatów pospolitych, przykładowo w danej dekadzie, o tym samym wykładniku afiksalnym, np. trans- w t, $\mathbf{g}, \mathbf{p}, \mathbf{l}$.

Q9.

Ile wynosi opóźnienie liczone w latach pomiędzy pojawieniem się neonimu a jego derywatem z taktu $k$ ze względu na t, $\mathbf{g}, \mathbf{p}, \mathbf{l}$ ?

Komentarz: gdyby wystąpiła silna korelacja ze względu na cechę z g, wówczas uzyskano by wniosek: istnieje korelacja prędkości tworzenia derywatów odneonimicznych z miejscem geograficznym powstawania tekstu, rozpatrywanym w duchu parametrów geograficznych z Wierzchoń 2008 (np. zbiór tekstów z wielkich miast wojewódzkich a zbiór gazetek lokalnych, gminnych czy wręcz - powstających w obrębie jednej wsi, np. pod koniec XX w.); innymi słowy - odpowiedź na to pytanie byłaby odpowiedzią o charakterze socjoderywatologicznym.

Q10.

Jaka wielkość dwu zmian procentowych frekwencji jednostki leksykalnej w jakim okresie prowadzi do stwierdzenia tzw. ponownej nominacji ze względu na t, $\mathbf{g}, \mathbf{p}, \mathbf{l}$ ? 
Piotr Wierzchoń: Na jakie pytania mógtby odpowiedzieć tworzony $w$ 2. dekadzie XXI $w$. model leksykalno-derywacyjny polszczyzny XX $w$.?

Q11.

Jaki jest inwentarz derywatów odnazwiskowych ze względu na t, g, p, l w C?

Q12.

Jaki jest inwentarz derywatów odskrótowcowych ze względu na t, g, p, $\mathbf{l}$ w C?

Q13.

W jakim zakresie kwantytatywnym tworzone są jakie kategorie pojęciowe wyrażane słowotwórczo ze względu na t, g, p, 1 w $\mathbf{C}$ ?

Komentarz: ontologia kategorii słowotwórczych za np. R. Grzegorczykową i J. Puzyniną (Gramatyka wspótczesnego języka polskiego. Morfologia); ontologia przetestowana w ujęciu np. K. Kleszczowej (rzeczownik staropolski) czy E. Kwapień (rzeczownik XIX w.).

Q14.

Jaka jest rodzina pól leksykalno-semantycznych w $\mathbf{C}$ ze względu na t, $\mathbf{g}, \mathbf{p}$, 1 ?

Komentarz: ontologia pól za np. St. Dubiszem (przykładowo z modyfikacją w aplikacji E. Kwapień dla słownictwa XIX w.) lub np. za Historical Thesaurus of the Oxford English (Kay i in. 2009).

Q15.

W jakim zakresie kwantytatywnym w jakim $\mathbf{C}$ występują tzw. konkurujące formanty w $\mathbf{t}, \mathbf{g}, \mathbf{p}, \mathbf{l}$ ?

Komentarz: na uwadze ma się tu konkurencję formantów typu przejście -nik w -arz (por. łapownik // łapówkarz) czy -owicz i -owiec, w którym to sporze H. Jadacka - M. Szczyszek, polegającym na ocenie konkurencji produktywności -owicz i -owiec, w oczywisty sposób rację ma H. Jadacka; M. Szczyszek zwraca uwage H. Jadackiej, iż H. Jadacka bada dysproporcjonalny materiał na niekorzyść -owicz; być może tak jest, ale wówczas M. Szczyszek bada superdysproporcjonalny materiał na korzyść -owicz.

Q16.

W jakim zakresie kwantytatywnym w jakim C stwierdza się diagnostyczny udział gniazda derywacyjnego w obrębie zadania konstruowania modelu $\mathrm{XX}$ w. ze względu na wartości parametrów $\mathbf{t}, \mathbf{g}, \mathbf{p}, \mathbf{l}$ ?

Komentarz: materiał oferowany w roku 2011 przez $\boldsymbol{T L C H}$ umożliwia już powrót do tezy H. Jadackiej (2001: 33), że w celu opracowania modelu polszczyzny XX w. należy odejść od analiz gniazdowych na rzecz tzw. słowotwórstwa binarnego; co prawda na s. 34 swojego modelu H. Jadacka zapowiada przeprowadzenie pewnych wnioskowań dotyczących upowszechnienia neonimu na podstawie faktu istnienia bardziej rozbudowanych gniazd, jednak w całości modelu informacje te poginęły; generalnie w powyższym pytaniu chodzi o weryfikację, abstrahując od faktycznie skolekcjonowanego materiału Badaczki, jednej hipotezy H. Jadackiej: „(...) neo- 
logizmy czasem tworzą nowe gniazda, częściej jednak uzupełniają (w sposób raczej nieregularny [podkr. - P.W.]) już istniejące” (Jadacka 2001: 33).

Q17.

Jaka jest proporcja udziału nowych formantów w C, np. 2. poł. XX w., w odniesieniu do formantów przykładowo 1. poł. XX w., ze względu na odmienną postać fonologiczną (graficzną) do nowych formantów o identycznej postaci fonologicznej, lecz o różnej funkcji, ze względu na t, g, p, l?

Komentarz: na uwadze ma się zbadanie „pędu” (pęd równa się: prędkość razy masa; prędkość to liczba lat, masa to frekwencja) diachronicznego w zakresie dynamiki wzrostu nowych fonologicznie form $v s$. nowych znaczeń w obrębie tego samego wykładnika formalnego (pojawia się problem pomiaru stopnia homonimizacji formantów, np. ciągu diakrytów euro, w - za Waszakową 2005 - euro-I, II, III: ze względu na t, g, p, l).

\section{Q18.}

Czy (lub w jakim zakresie kwantytatywnym) stwierdza się diagnostyczny udział kategorii przysłówka w obrębie zadania konstruowania modelu XX w. ze względu na wartości parametrów $\mathbf{t ,}, \mathbf{g}, \mathbf{p}, \mathbf{l}$ ?

Komentarz: jakie argumenty mogłyby doprowadzić do uwzględnienia w teorii opisu polszczyzny XX w. kategorii przysłówka, np. w celach diagnostycznych dotyczących słowotwórstwa lewostronnego, tj. chodzi o przebadanie, czy istnieje diagnostyczna korelacja pomiędzy liczbą prefiksowanych elementów kategorii przysłówka a produktywnością danego prefiksu, obliczaną na podstawie analizy pozostałych kategorii części mowy, głównie rzeczownika i przymiotnika; inaczej: jakie argumenty o charakterze wyraźnie kwantytatywnym mogłyby spowodować wzięcie pod uwagę ewentualnej zmiany stanowiska H. Jadackiej (2010) w odniesieniu do kategorii przysłówka?

\section{Q19.}

Które formanty wchodzą w relację, którą K. Kleszczowa nazywa tzw. przełamywaniem barier części mowy, w akcie derywacyjnym ze względu na t, $\mathbf{g}, \mathbf{p}, \mathbf{l}$ w $\mathbf{C}$ ?

Komentarz: idzie o wyodrębnienie wspólnych formantów, zapewne tylko lewostronnych, dla wszystkich możliwych podzbiorów części mowy.

Q20.

Jak przedstawia się ontologia członów konkatenujących rzeczownikowego duonimu ze względu na $\mathbf{t}, \mathbf{g}, \mathbf{p}, \mathbf{l}$ w $\mathbf{C}$ ?

Komentarz: zadanie polega na stworzeniu nazw zbiorów (kategorii semantycznych), do których należą, osobno, pierwsze i drugie człony duonimu (dywizowego zrostu apozycyjnego) np. 1. i 2. poł. XX w.; np.: aparat-automat, aparat-detefon, apostot-asystent, apostot-biskup, apostot-laik, apostot-męczennik, aptekarz-chemik, aptekarz-kierownik, aptekarz-przyrodnik, archeolog-amator, archeolog-historyk, archeolog-pre-histo- 
Piotr Wierzchoń: Na jakie pytania mógtby odpowiedzieć tworzony $w$ 2. dekadzie XXI $w$. model leksykalno-derywacyjny polszczyzny XX $w$.?

ryk, architekt-akademik, architekt-artysta, architekt-autor, architekt-dekorator, architekt-inżynier, architekt-kapitan, architekt-kierownik, architekt-konserwator, architekt-konstruktor, architekt-modernista, architekt-nowator, architekt-ogrodnik, architekt-pionier, architekt-planista, architekt-poeta, architekt-Polak, architekt-projektodawca, architekt-rzeczoznawca, architekt-szpitalnik, architekt-twórca, architekt-urbanista itd.

Q21.

Jakie jest opóźnienie czasowe (liczba lat), które występuje w słownictwie XX w. pomiędzy pojawieniem się apozycji a jej zanikiem i usamodzielnieniem się członu hiponimicznego, np. maszyna nawijarka > nawijarka, maszyna wrębiarka > wrębiarka, film kreskówka > kreskówka itd. wt, $\mathbf{g}, \mathbf{p}, \mathbf{l}$ ?

Komentarz: nawijarka, wrębiarka (itp. - zwłaszcza: nazwy narzędzi z przyrostkiem -arka), kreskówka to neonimy przedwojenne, a nie powojenne - jak ustalono w literaturze przedmiotu (Jadacka 2001: 184, 48, Smółkowa 1976: 132).

Q22.

Jak przedstawia się zbiór relacji wartościujących na poziomie morfologicznym ze względu na $\mathbf{t}, \mathbf{g}, \mathbf{p}, \mathbf{l}$ w $\mathbf{C}$ ?

Komentarz: stworzenie inwentarza formantów 1901-2000 o danej wartości aksjologicznej; podstawa metodologiczna - np. Jadacka 1978, Waszakowa 1991.

Q23.

Jaka jest korelacja stopnia autorytetu lokutora z produktywnością formantów słowotwórczych ze względu na $\mathbf{t}, \mathbf{g}, \mathbf{p}, \mathbf{l}$ w $\mathbf{C}$ ?

Komentarz: w modelu systemu XX w. można postawić pytanie o zasadność wprowadzenia do opisu słowotwórstwa informacji dotyczącej kategorii autorytetu językowego na prawach parametru, tj. np. na uwadze ma się śledzenie w materiale prasowym tego, kto (przykładowo polityk) użył danego derywatu o danej strukturze; por. wzrost (i spadek) dynamiki produktywność formatu lże- po wystąpieniu J. Kaczyńskiego.

\section{Q24.}

Czy jest nowa porcja argumentów kwantytatywnych w dyskusji dotyczącej uzasadnienia rozróżnienia pomiędzy prefiksem a elementem złożenia, np. dla tzw. prefiksoidów typu: anty-, ekstra- itd. ze względu na t, $\mathbf{g}, \mathbf{p}, \mathbf{l}$ w $\mathbf{C}$ ?

Komentarz: zgromadzenie nowych danych kwantytatywnych (udział w strefie aktywności) i frekwencyjnych (frekwencja tekstowa derywatów o danym formancie z danej strefy) pozwoli podjąc próbę wypracowania mierzalnych kryteriów uznania formantu za prefiks lub człon złożenia; skombinowanie parametrów: frekwencja, semantyka członów konkatenujących, argumentów stylometrycznych, tekstologicznych itd. powinno rzucić nowe tekstologiczne światło $\mathrm{w}$ dyskusji nad aparatem pojęciowym słowotwórstwa synchronicznego. 
Q25.

Jaki jest udział procentowy formantów obcych w derywacji lewo- i prawostronnej derywatów, biorąc pod uwagę parametr części mowy, ze względu na t, g, p, 1 w $\mathbf{C}$ ?

Komentarz: w obrębie jakiej części mowy następuje preferencja jakiego genetycznie formantu w jakim czasie (dodatkowo: w zależności od frekwencji tekstowej podstawy derywacji)?

Q26.

Jaka jest korelacja pomiędzy wysokością nakładu czasopisma a produktywnością morfemów ujętych w czasopiśmie ze względu na t, g, p, l w C?

Komentarz: przebadanie, czy wielkość nakładu czasopisma ma związek z dynamiką produktywności danych afiksów.

Q27.

Jaka jest frekwencja członów złożeń ze względu na t, g, p, 1 w C?

Komentarz: jakie człony najczęściej tworzą złożenia (i w jakich dekadach)?

\section{Q28.}

Jaki jest udział kategorii pluralia tantum ze względu na t, g, p, 1 w C?

Komentarz: rajtki - jednostka leksykalna uznawana za neonim powojenny (Smółkowa 1976: 150) - nie jest neonimem powojennym; liczba den, dtex itp. - nieuwzględniona w Smółkowa 1976.

\section{Q29.}

Które zbiory par formantów prefiksalno-sufiksalnych występują najczęściej w strukturze derywatu ze względu na $\mathbf{t}, \mathbf{g}, \mathbf{p}, \mathbf{l}$ w $\mathbf{C}$ ?

Q3o.

Które zbiory formantów prefiksalno-sufiksalnych nie współwystępują w strukturze derywatu ze względu na t, g, p, l w C?

Q31.

Które formanty w prefiksalnych ciągach dwuformantowych występują częściej na danej pozycji ze względu na $\mathbf{t}, \mathbf{g}, \mathbf{p}, \mathbf{l}$ w $\mathbf{C}$ ?

Komentarz: przykładowo, który element częściej występuje na danej pozycji (bioradjo- czy radjobio-)?

Q32.

Jaka jest korelacja pomiędzy wielkością formantu liczoną w znakach (np. $a-$, do-, bez-, anty-, ponad- itd.) a jego produktywnością ze względu na $\mathbf{t}, \mathbf{g}, \mathbf{p}, \mathbf{l}$ w $\mathbf{C}$ ?

Komentarz: czy istnieje zależność pomiędzy tendencją do ekonomizacji (minimalizacja liczby znaków w morfemach) a tendencją do wyrazistości semantycznej (maksymalizacja liczby znaków w morfemach) ze względu na $\mathbf{t}, \mathbf{g}, \mathbf{p}, \mathbf{l}$ ? 
Piotr Wierzchoń: Na jakie pytania mógtby odpowiedzieć tworzony $w$ 2. dekadzie XXI $w$. model leksykalno-derywacyjny polszczyzny XX $w$.?

Q33.

Jakie przymiotniki wchodzą najczęściej w złożenia łącznikowe (np. administracyjno-prawniczny itp.) ze względu na $\mathbf{t}, \mathbf{g}, \mathbf{p}, \mathbf{l}$ w $\mathbf{C}$ ?

Komentarz: czy istnieje korelacja pomiędzy produktywnością duonimiczną jednostki leksykalnej, tj. jej zdolnością do wchodzenia w łącznikowe relacje duonimiczne, a jej frekwencją tekstową; innymi słowy: czy duonim polski, osobno dla 1. i 2. poł. XX w., tworzony jest w pierwszym członie $\mathrm{z}$ jednostek o wyższych frekwencjach tekstowych?

Q34.

Jaki jest udział części mowy w obrębie neonimów ze względu na granicę datacji $x$, ze względu na $\mathbf{t}, \mathbf{g}, \mathbf{p}, \mathbf{l}$ w $\mathbf{C}$ ?

Komentarz: w literaturze przedmiotu mówi się o szczególnie wysokim przyroście w obrębie XX w. elementów kategorii nominalnych.

\section{Q35.}

Jaka jest korelacja pomiędzy derywatami o tym samym wykładniku formalnym (afiksie) następujących w tekście bezpośrednio po sobie a ich frekwencją ze względu na t, g, p, $\mathbf{l}$ w $\mathbf{C}$ ?

Komentarz: hipoteza - derywaty o tym samym wykładniku formalnym (afiksie) następujące w tekście bezpośrednio po sobie (w skupieniu) należą do zbioru okazjonalizmów, są wynikiem neonimizowania (iteracji neonimicznej); w rozszerzeniu pytanie to dotyczy: derywatów utworzonych w tej samej technice derywacji (np. paradygmatycznej czy ujemnej).

\section{Q36.}

Jaka jest frekwencja operatorów testymonialności dla neonimu 1. i 2. poł. $\mathrm{XX}$ w. ze względu na $\mathbf{t}, \mathbf{g}, \mathbf{p}, \mathbf{l}$ w $\mathbf{C}$ ?

Komentarz: neonimy, pojawiające się w tekstach, poprzedzają niekiedy operatory testymonialności; rodzi się pytanie o zakres ich użycia we wszystkich możliwych podokresach XX w., czyli w $\mathbf{C}$.

\section{Q37.}

Jaka jest statystyka formantów słowotwórczych w $\mathbf{C}$ obliczanych osobno dla subkodu pisanego oraz mówionego (badanie wykonalne jedynie dla przełomu XX i XXI w.) ze względu na t, g, p, l, przy czym dla subkodu mówionego utrzymuje się dwa parametry $\mathbf{t}$ i $\mathbf{l}$, gdzie parametr $\mathbf{l}$, jako parametr lokalizacji tekstowej, ocechowany jest minutowo?

Komentarz: pytanie to pojawia się ze względu na trafne spostrzeżenie M. Szczyszka (2010).

Powyżej przedstawiono wstępną listę pytań, na jakie mógłby odpowiedzieć wielki model leksykalno-derywacyjny polszczyzny XX w.

Aby sporządzić taki model, należałoby, po pierwsze, przebadać frekwencyjnie - ze względu na parametry t, $\mathbf{g}, \mathbf{p}, \mathbf{l}$ ujęte w powyższych pytaniach - tekst XX w., dostępny od roku 2002 (por. Mazurek i in. 2011) 
w postaci fotodokumentacyjnej w polskich bibliotekach cyfrowych. Liczba tych dokumentów, np. czasopism z XX w., wynosi obecnie kilkaset tysięcy obiektów bibliotecznych. Dlatego należy:

a) sporządzić listę tekstów (od kilkudziesięciu do kilkuset tysięcy), z których zamierza się wyodrębnić materiał empiryczny w postaci jednostek ocechowanych ze względu na wartości parametrów $\mathbf{t}, \mathbf{g}, \mathbf{p}, \mathbf{l}$,

b) poddać teksty ekscerpcji - por. np. wynik takiej ekscerpcji dla 1. poł. XX w. w Depozytorium leksykalnym języka polskiego... (Wierzchoń 2010); ekscerpcja ta, tzn. poprzedzająca analizy derywatologiczne jednostek leksykalnych XX w., łącznie z prezentacją fotodokumentacyjną, może potrwać kilkadziesiąt miesięcy (kilka lat),

c) podzielić zbiór jednostek leksykalnych XX w. na zbiory neonimów względem granicy datacji roku 1945; ustalenie to zajmie dodatkowe miesiace pracy i stanowi osobne zadanie badawcze,

d) podzielić zbiór jednostek leksykalnych XX w. na zbiory neonimów względem wszystkich granic datacji XX w.; ustalenie to zajmie kilka lat,

e) przeanalizować każdy tak osiągnięty derywat według parametrów ujętych w powyższych pytaniach (Q1.-Q37.), co wymaga poświęcenia kolejnych lat pracy,

f) podać wyniki kwantytatywne, uzyskane wskutek przebadania np. kilkuset tysięcy jednostek leksykalnych; czynność ta nie powinna zająć zbyt wiele czasu (kilka miesięcy),

g) opracować komponent wizualizacji, efektywnie ukazujący osiągnięte wyniki frekwencyjne analiz leksykalno-derywacyjnych (ponieważ liczba parametrów biorących udział w analizie derywatu polskiego XX w. zbliża się do kilkudziesięciu, wizualizacja wyniku wymaga opracowania osobnego sposobu prezentacji danych).

Po drugie, należałoby przebadać tak uzyskaną i scharakteryzowaną (ze względu na: t, $\mathbf{g}, \mathbf{p}, \mathbf{l})$ bazę jednostek języka ze względu na pytania Q1.-Q37.

Reasumując, powyżej była mowa (Postulat wykonalności) o praktycznej wykonalności modelu polszczyzny XX w. Mówiąc o praktycznej wykonalności, mamy na uwadze realny skutek w postaci np. opublikowanej treści modeli Jadacka 2001 czy Waszakowa 2005. Model, opracowany na podstawie ujętych powyżej pytań, pozwoliłby w sposób sparametryzowany odpowiedzieć np. na pytanie: jak rozpoznać tzw. szybkie lub wolne tempo zmian leksykalnych? Co to jest duża i mała dynamika zmian? Itp.

Rodzi się obecnie pytanie: jak przedstawia się rodzina zbiorów pytań, tzn. zbiór zbiorów $\mathbf{Q}$, na które mógłby odpowiedzieć wielki model polszczyzny XX w. tworzony w 2. dekadzie XXI w.? Innymi słowy, jakie ciągi zadań ujęte w pytania, np.: 
Piotr Wierzchoń: Na jakie pytania mógtby odpowiedzieć tworzony $w$ 2. dekadzie XXI $w$. model leksykalno-derywacyjny polszczyzny XX $w$.?

a) Q1., Q2., Q3., Q4., Q5., Q6., Q7., Q8., Q9., Q10., Q11., Q12., Q13., Q14., Q15., Q16., Q17., Q18., Q19., Q20., Q21., Q22., Q23., Q24., Q25., Q26., Q27., Q28., Q29., Q30., Q31., Q32., Q33., Q34., Q35., Q36., Q37.,

b) Q1., Q2., Q3., Q4., Q5., Q6., Q7., Q8., Q9., Q10., Q11.,

c) Q1., Q4., Q7., Q10., Q11., Q12., Q14., Q17., Q18., Q19., Q21., Q22., Q23., Q24., Q25., Q26.,

d) Q4., Q6., Q10., Q11., Q17., Q21., Q33., Q34., Q35.,

e) Q23.

f) Q37.,

g) Q10., Q15., Q16., Q17., Q19., Q21., Q22., Q30., Q31., Q32., Q33.

h) Q1., Q2., Q3.,

i) itd.

uznać można za praktycznie wykonalne:

a) w iluosobowym zespole ekspertów o jakiej kompetencji:

- lingwistycznej

- korpusologicznej (przygotowanie realnego, empirycznego materiału badań, bez którego kolejne punkty projektu tracą rację bytu),

- lingwochronologizacyjnej (określenie chronologizacji lub neonimiczności badanych jednostek),

- semantycznej (wykonalno-leksykologicznej),

- ortograficznej (instytucjonalne reformy ortografii XX w.),

- kresoznawczej (duży komponent polszczyzny poza wschodnimi granicami kraju),

- polonijnej (uwzględnienie istotnych porcji tekstów polonijnych, np. czasopism),

- prasoznawczej (uwzględnienie parametrów prasoznawczych),

- stylistycznej (stratyfikacja stylistyczna typu tekstu),

- derywatologicznej (ustalanie granic morfologicznych, wyodrębnianie formantów, ocena technik derywacyjnych w zakresie typu derywacji),

- etymologicznej (ocena kierunku wzbogacania systemu polszczyzny XX w.),

- itd.

- informatycznej (obsługa baz danych tworzonych ze względu na parametry w t, g, p, l i C oraz Q1.-Q37.),

- inżynieryjnej, polegającej na:

- teoretycznym zaprojektowaniu, 
- przetestowaniu,

- rozruchu,

- konserwacji (np. w zakresie rozbudowy o nowe moduły)

linii technologicznej prowadzącej do realnego uzyskania modelu polszczyzny XX w.,

- menedżersko-prakseologicznej (realne, niepustosłowne regulowanie Czynu: kolejkowanie zadań, przydzielanie dostępnych zasobów - odpowiedzialność „producencka” za efekt),

- towarzyskiej (dbanie o miłą atmosferę pracy, wyzwalanie wzajemnej serdeczności; oferta pogody ducha, wspieranie w trudnych tzw. życiowych sprawach itp.),

- itp.,

b) dla jak dużej bazy indywiduów (ile tysięcy jednostek leksykalnych do przebadania w Q1.-Q37.),

c) z jaką ilustracją kontekstową $\mathbf{x}$ tysięcy jednostek:

- bez ilustracji (np. Jadacka 2001),

- z transkrypcją kontekstów (np. Smółkowa 1998),

- z oryginalnym poświadczeniem w postaci fotodokumentacyjnej (np. Wierzchoń 2008),

d) z jaką szczegółowością eksplikacji semantycznych (np. eksplikacja strukturalno-znaczeniowa vs. eksplikacja T, DT, R, tj. na temat, dictum tematyczne, remat),

e) w jakim czasie (ile miesięcy),

f) dysponując jakimi funduszami jak rozdysponowanymi:

- aparatura,

- koszty zasobów ludzkich.

Innymi słowy: rodzi się pytanie, jak podzielić powyższe pytania Q1.-Q37. na podzbiory o jakiej wykonalności? Widać bowiem z powyższej propozycji ustalenia ciągów Q1., Q2., Q3.... Q37., że niektóre zadania tak ustalone byłyby ważniejsze dla poznania ewolucji systemu morfologicznego XX w. Np. najważniejszym pytaniem byłoby zapewne $\mathbf{Q 1}$ w $\mathbf{C}_{1 \text { (1901-1939) }}$ i $\mathbf{C}_{2 \text { (1945-200o). }}$

Czym innym jest ważność pytania, a czym innym jego wykonalność. Przykładowo, obecnie wykonalność Q37. stoi pod znakiem zapytania. Tak więc mniej czasu zajmie wyodrębnienie jednostek prefiksalnych $\mathrm{z}$ bazy empirycznej niż wyodrębnienie derywatów powstałych w wyniku derywacji ujemnej. Dyscypliną, która reguluje te wybory, jest prakseologia-inżynieria systemów.

W kolejnym kroku model ten należy podzielić na dwa submodele, tj.: 
Piotr Wierzchoń: Na jakie pytania mógtby odpowiedzieć tworzony $w$ 2. dekadzie XXI $w$. model leksykalno-derywacyjny polszczyzny XX $w$.?

a) submodel neonimiczny,

b) submodel nieneonimiczny.

Modele Jadacka 2001, Smółkowa 1976 czy Waszakowa 2005 były modelami neonimicznymi. Krytyka neonimiczności tych modeli przeprowadzona przez piszącego te słowa w latach 2008-2011 doprowadziła go do konkluzji: aby opisać system słowotwórczy XX w. wyłącznie na podstawie jednostek neonimicznych względem danej granicy datacji, należy:

a) albo uwzględnić wyłącznie derywaty od podstaw zupełnie nowych (np. falandyzacja, watęsizm, akowiec itp.), co zapewni neonimiczność derywatu z dokładnością najprawdopodobniej dekadową,

b) albo zbudować model neonimiczny, lecz ze szczegółowym określeniem neonimiczności każdej jednostki ze względu na klasę wszystkich dyrektyw $\left(\boldsymbol{D}_{1}, \boldsymbol{D}_{\mathbf{2}}, \boldsymbol{D}_{\mathrm{n}}\right)$ prowadzących do uzyskania danej chronologizacji neonimicznej, np. ze względu na dowolną teorię chronologizacyjną (np. T. Smółkowej lub P. Wierzchonia).

Osobnym, najbardziej obiecującym rozwiązaniem metodologicznym jest budowa modelu nieneonimicznego (np. typu Kleszczowa 2003).

\section{Wizualizacja wyników chronologizacyjnych}

Ponieważ wynikiem działania teorii zmierzającej do opisu polszczyzny XX w. będą (ze względu na powyższe pytania) w głównej mierze dane kwantytatywne, nieodzowna wydaje się ich prezentacja graficzna. Poniżej przedstawia się przykładowe, najprostsze (jedynie dwuparametrowe) wyniki analiz kwantytatywnych dla materiału z przedziału 1920-1939 (osie poziome ilustrują wartości coroczne, osie pionowe: albo liczbę bezwzględną wystąpień danej jednost$\mathrm{ki}$, albo - jeżeli wyrażone są $\mathrm{w}$ wartościach ułamkowych - iloraz liczby wystąpień tekstowych do ogólnej liczby tekstów z danego roku):

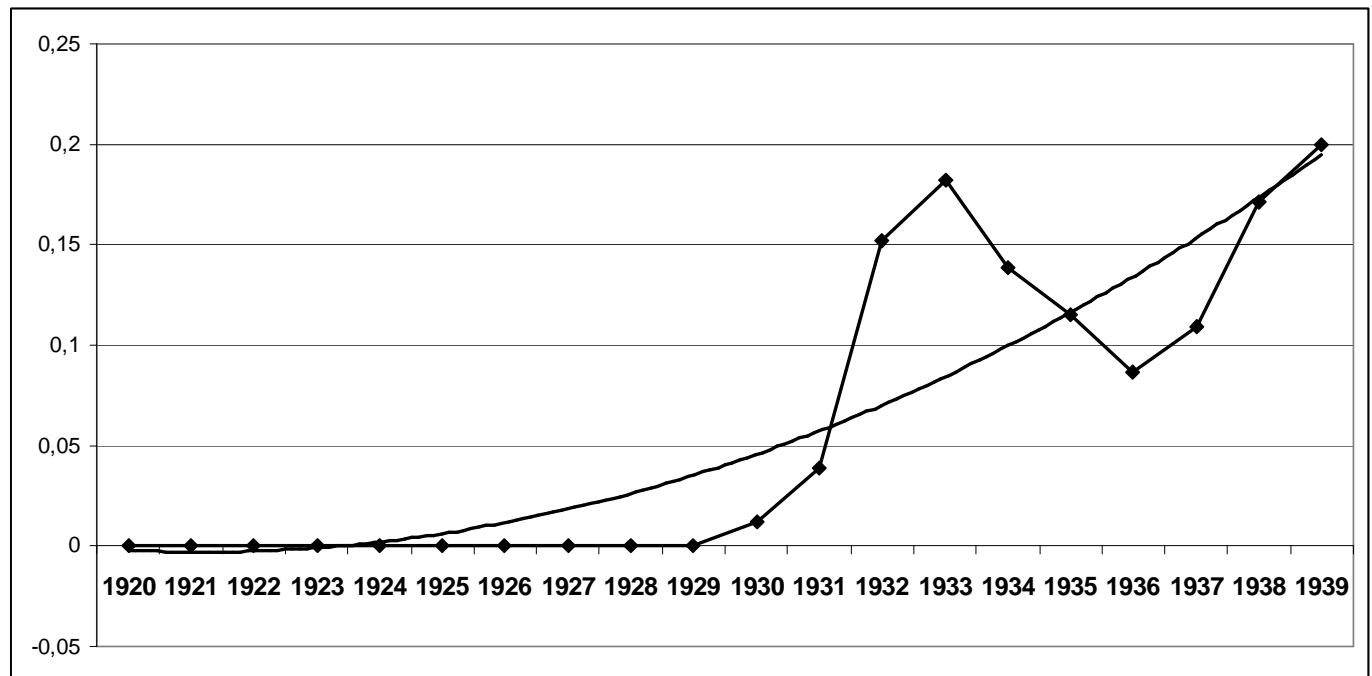

Wykres 1. Frekwencja w tekstach polskich Janusza Kusocińskiego 


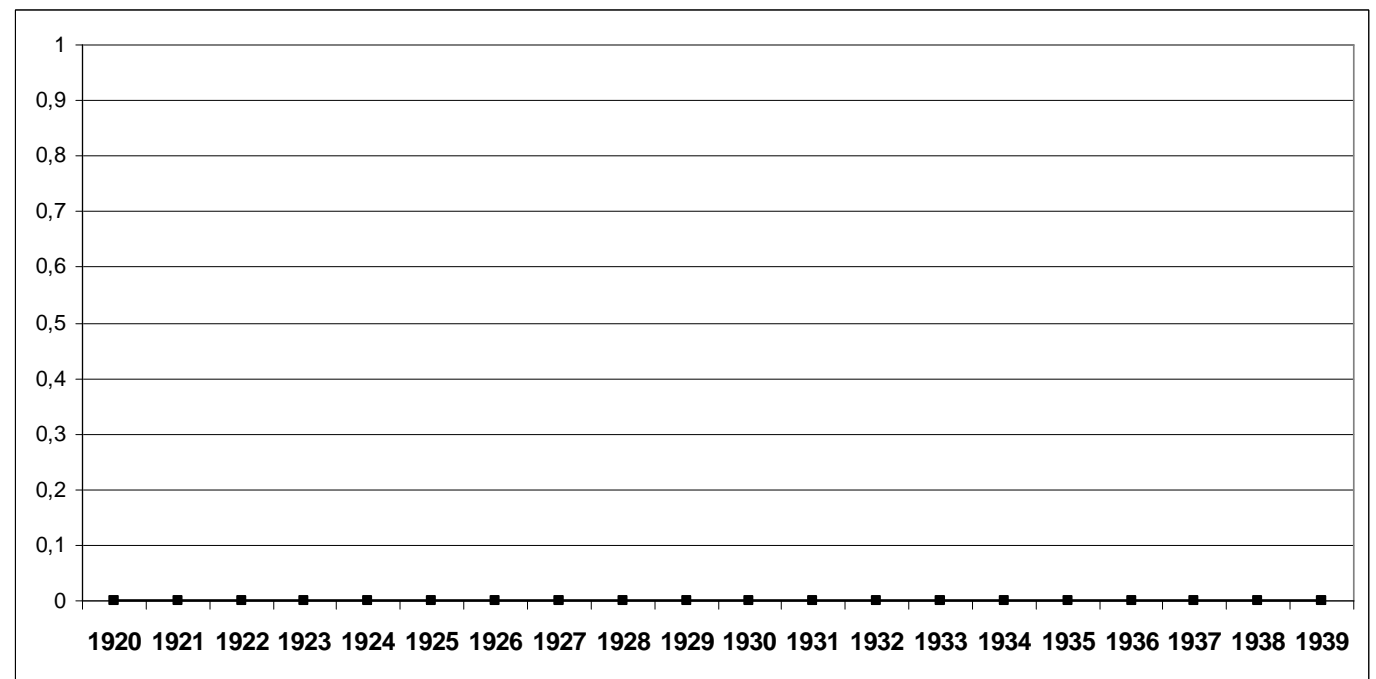

Wykres 2. Frekwencja nazwy polopiryna

Hipoteza: polopiryna to neonim powojenny.

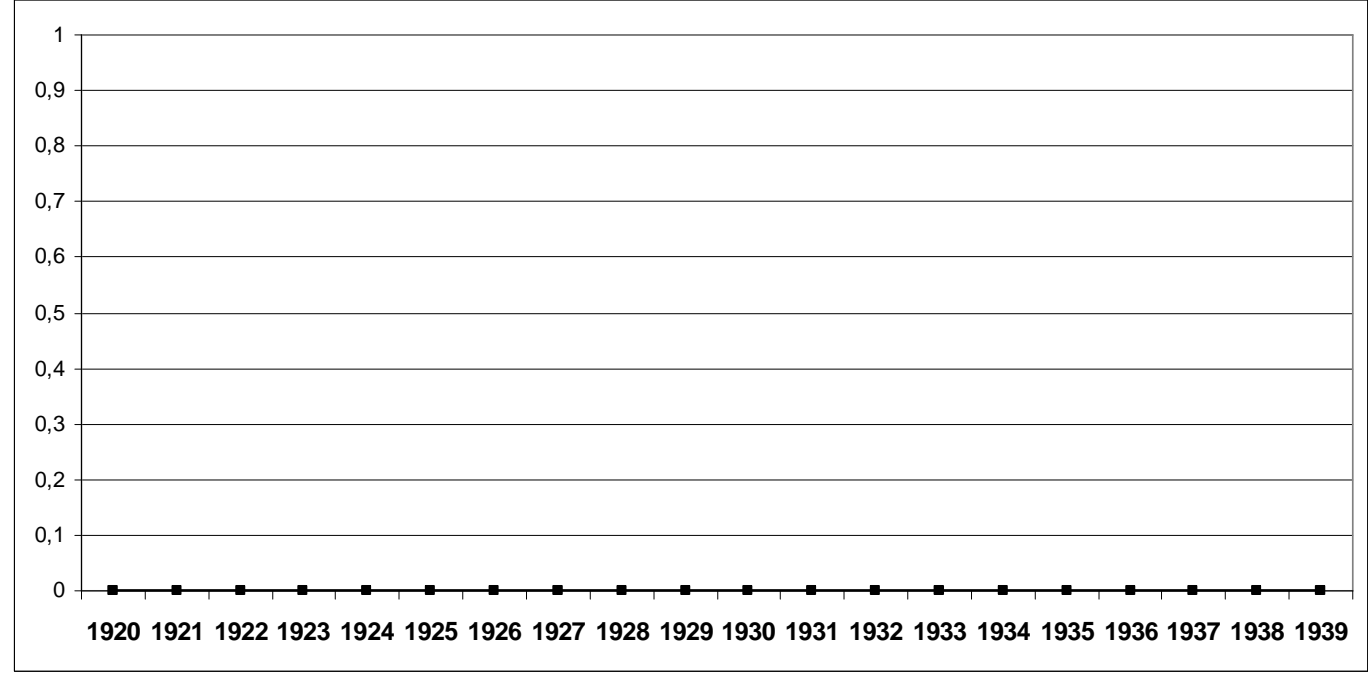

Wykres 3. Frekwencja derywatu podkolanówka

Hipoteza H. Jadackiej zakładająca powojenną chronologizację derywatu podkolanówka (Jadacka 2001: 57 za Smółkowa 1976: 145) została podtrzymana. 
Piotr Wierzchoń: Na jakie pytania mógtby odpowiedzieć tworzony $w$ 2. dekadzie XXI $w$. model leksykalno-derywacyjny polszczyzny XX $w$.?

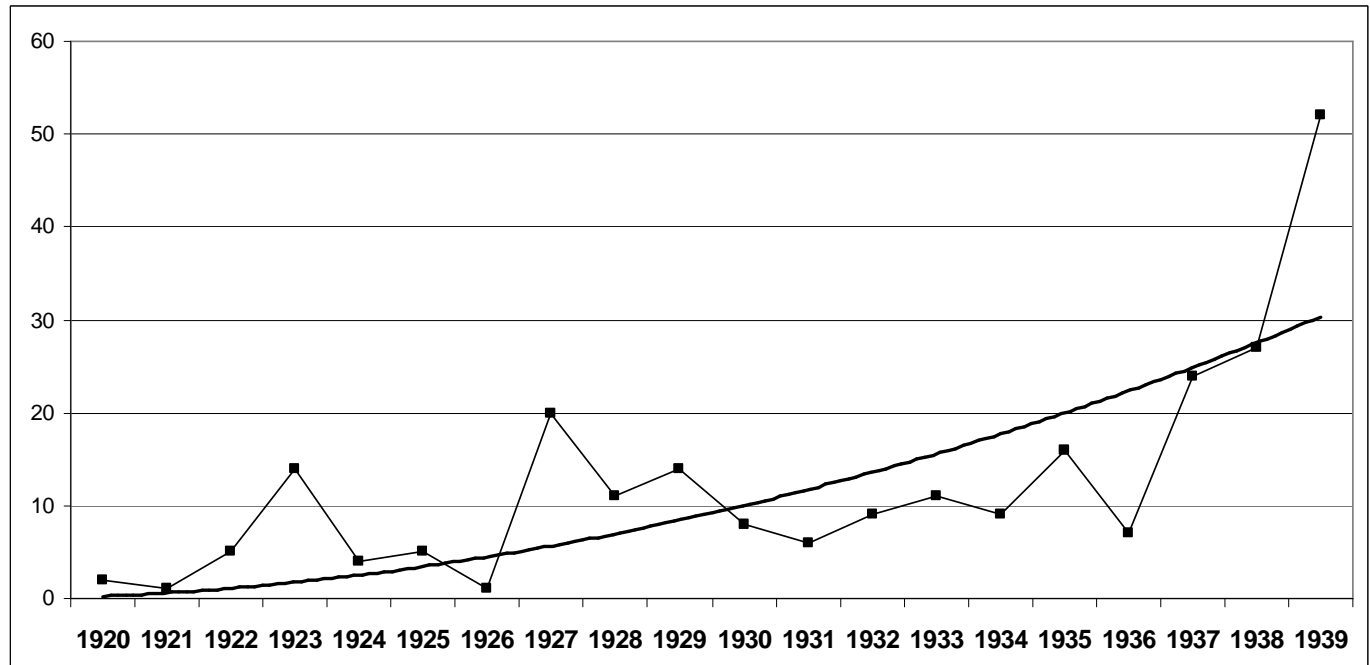

Wykres 4. Frekwencja derywatu dokumentacja

Hipoteza T. Smółkowej o powojennej chronologizacji derywatu dokumentacja (Smółkowa 1976: 120) została obalona.

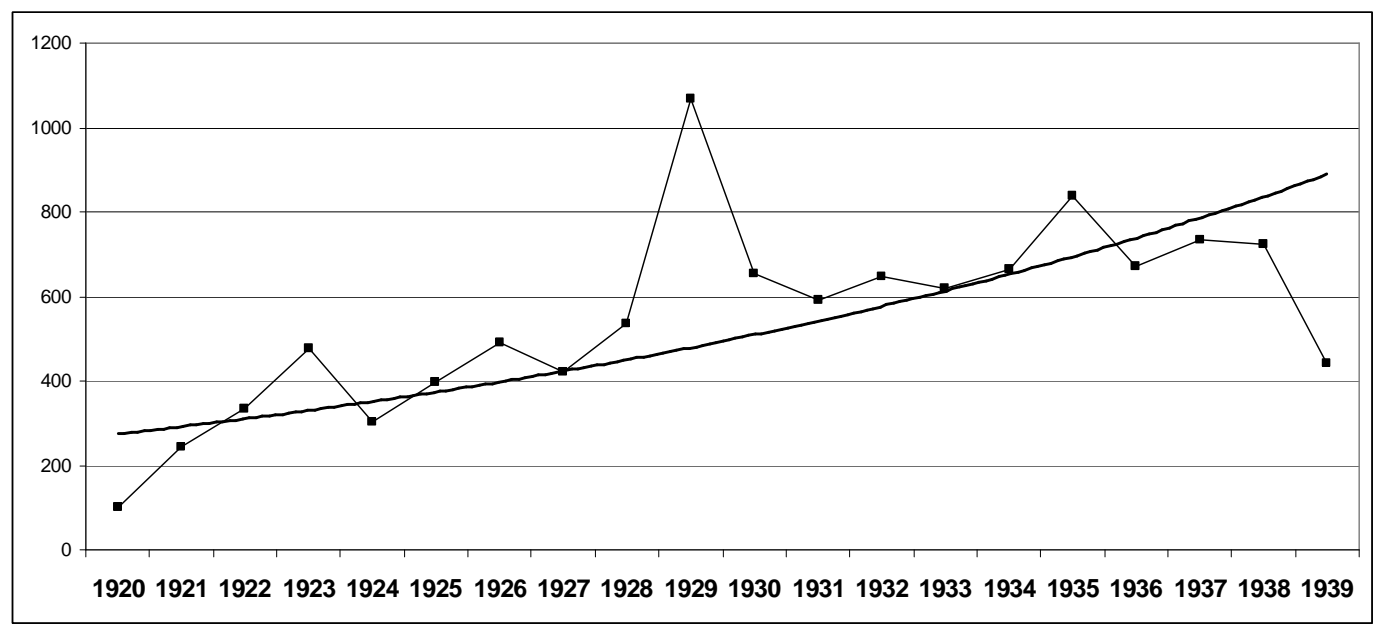

\section{Wykres 5. Frekwencja derywatu przemysłowo-handlowy}

Hipoteza T. Smółkowej dotycząca powojennej chronologizacji derywatu przemystowo-handlowy (Smółkowa 2001: 170) została obalona. W pracy Smółkowa 2009 wprowadza się tzw. kryterium upowszechnienia, wedle którego neonimem powojennym jest wyraz o jakoś wysokim stopniu upowszechnienia. Model Smółkowa 2001 notuje dwa (2) poświadczenia powojenne duonimu przemystowo-handlowy, co mogłoby wskazywać wedle tzw. kryterium upowszechnienia (Smółkowa 2009), tj. częstej frekwencji derywatu po danej granicy datacji, na powojenną neonimiczność przymiotnika przemystowo-handlowy. Wykres 5. opisuje ponad 10 ooo użyć tego przymiotnika w latach 1920-1939. Przemystowo-handlowy upowszechnił się przed rokiem 1939. 


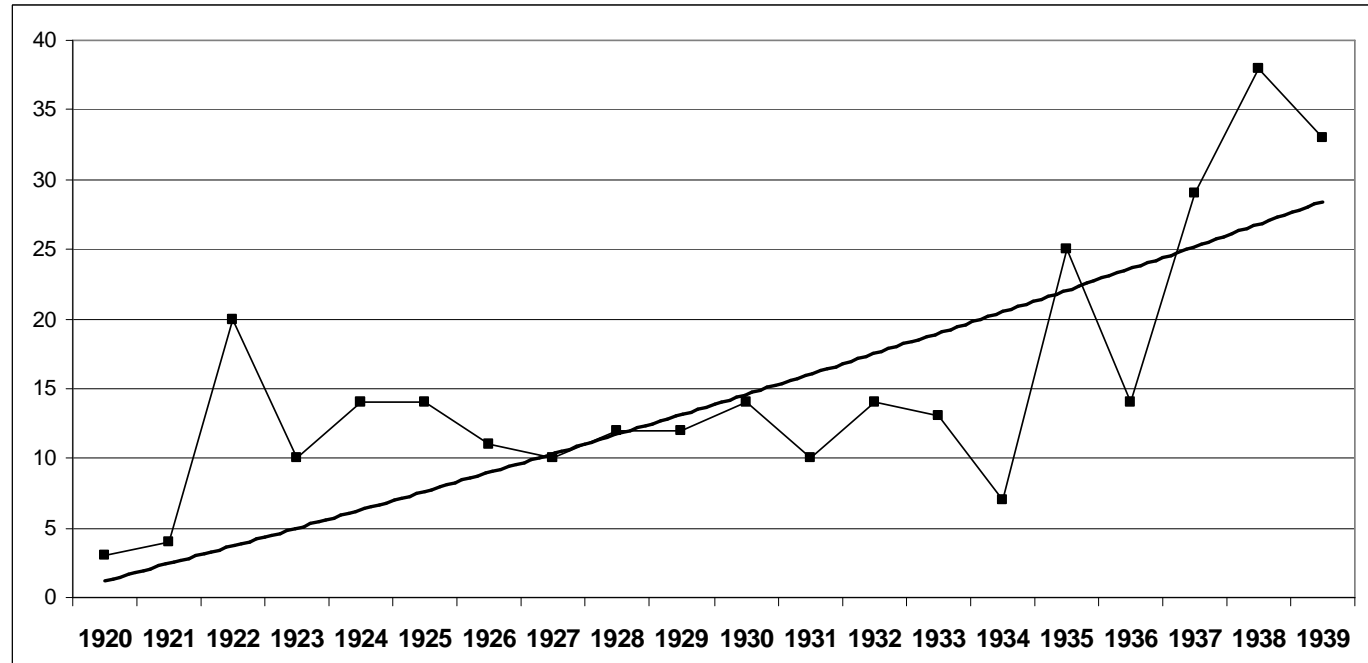

Wykres 6. Frekwencja derywatu recenzyjny

Hipoteza T. Smółkowej dotycząca powojennej chronologizacji derywatu recenzyjny (Smółkowa 2001: 172) została obalona. W pracy Smółkowa 2001 przymiotnik recenzyjny uzyskuje powojenną frekwencję $=1$. Wykres 6 . ilustruje ponad 300 użyć tego przymiotnika w latach 1920-1939. Derywat recenzyjny nie mógł się zatem upowszechnić po II wojnie światowej, gdyż był dobrze upowszechniony (występuje w kilkuset tekstach o różnym charakterze genologiczno-stylistycznym przed rokiem 1945).

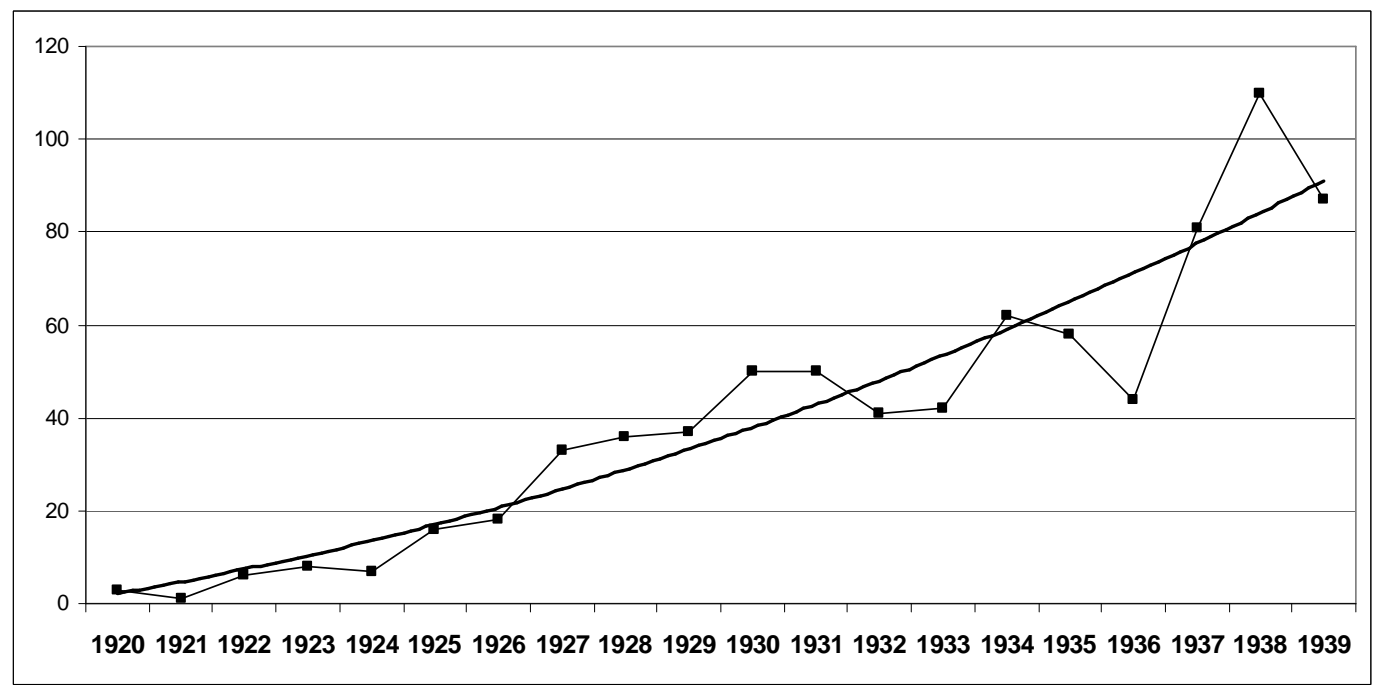

Wykres 7. Frekwencja derywatu przetwórstwo

Hipoteza T. Smółkowej dotycząca powojennej chronologizacji derywatu przetwórstwo (Smółkowa 1976: 149) została obalona. 
Piotr Wierzchoń: Na jakie pytania mógtby odpowiedzieć tworzony $w$ 2. dekadzie XXI $w$. model leksykalno-derywacyjny polszczyzny XX $w$.?

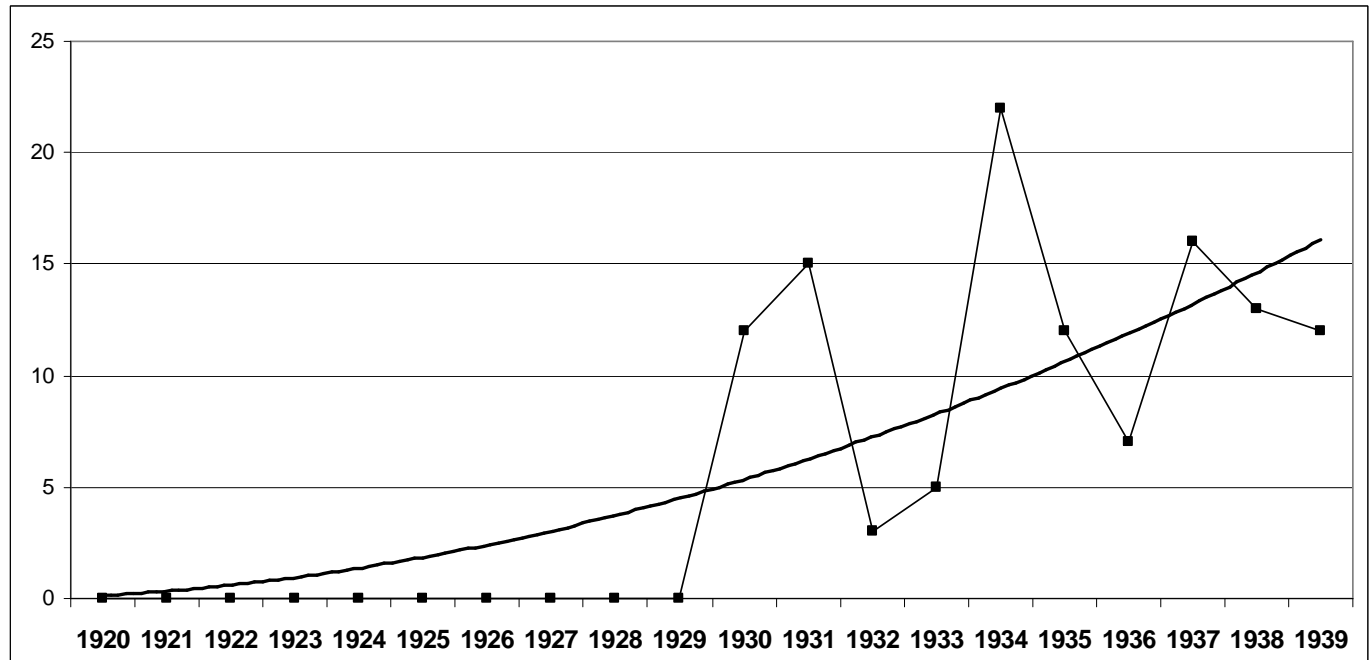

Wykres 8. Frekwencja derywatu krótkofalowiec

Hipoteza T. Smółkowej dotycząca powojennej chronologizacji neonimicznej derywatu krótkofalowiec (Smółkowa 1976: 133) została obalona.

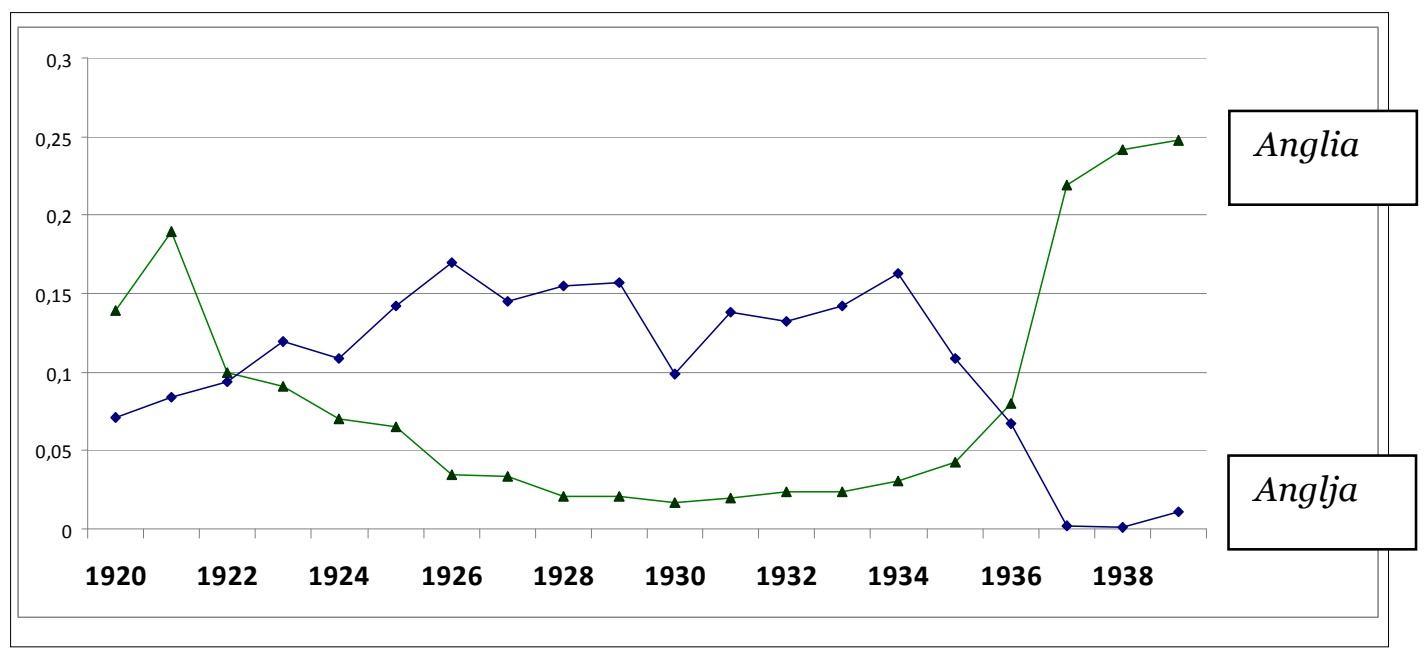

Wykres 9. Korelacja występowania form ortograficznych Anglia vs. Anglja ze względu na reformę ortografii w roku 1936

Komentarz: W związku z reformą ortografii frekwencja formy Anglja maleje, natomiast formy poprawnej po roku 1936 - Anglia - rośnie. 


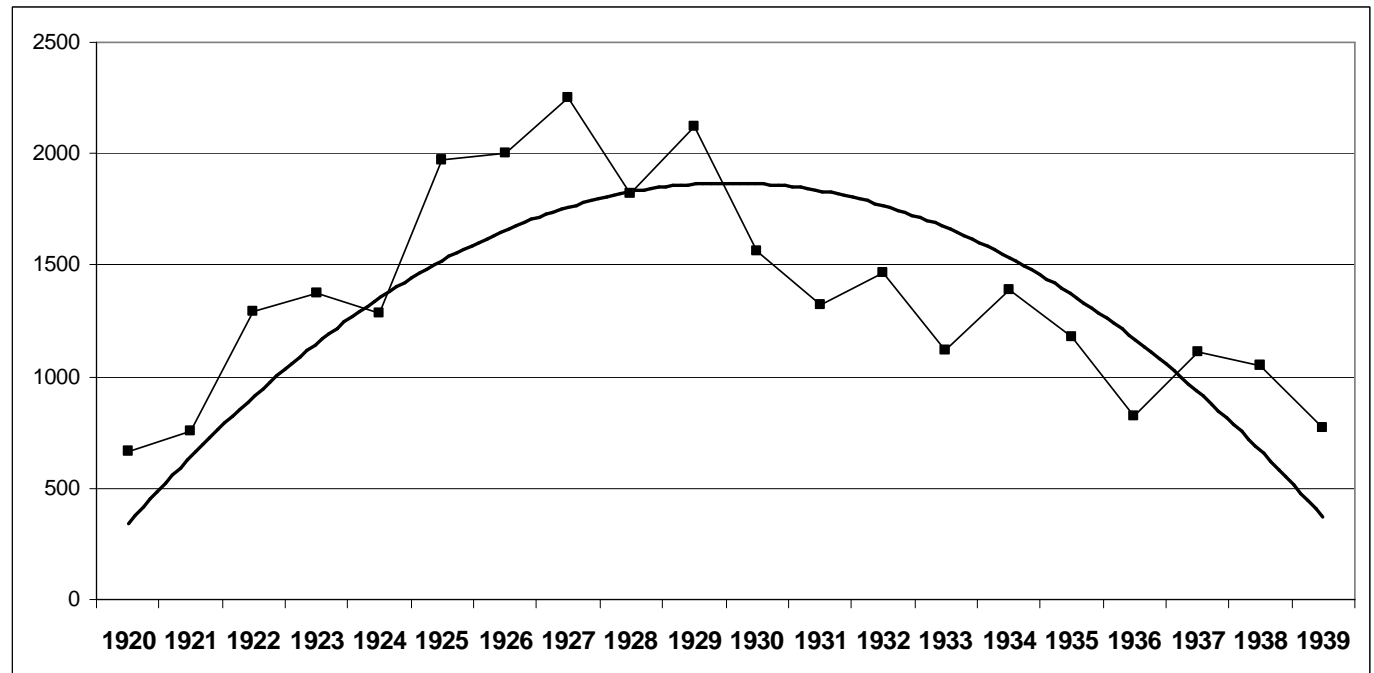

Wykres 10. Frekwencja form na arcy-

Komentarz: Liczba użyć derywatów z arcy- maleje w dwudziestoleciu międzywojennym.

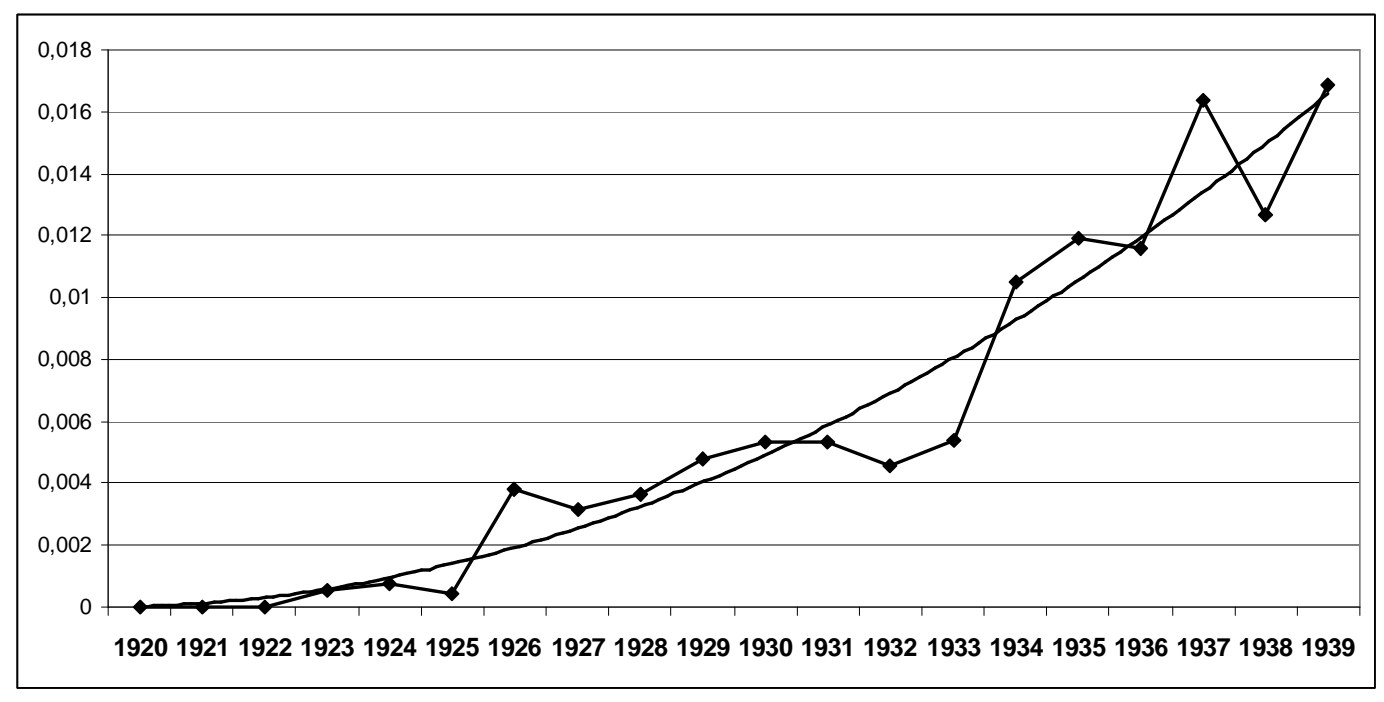

Wykres 11. Frekwencja derywatu telewizja

Hipoteza T. Smółkowej dotycząca powojennej chronologizacji derywatu telewizja (Smółkowa 1976: 158) została obalona. 
Piotr Wierzchoń: Na jakie pytania mógtby odpowiedzieć tworzony $w$ 2. dekadzie XXI $w$. model leksykalno-derywacyjny polszczyzny XX $w$.?

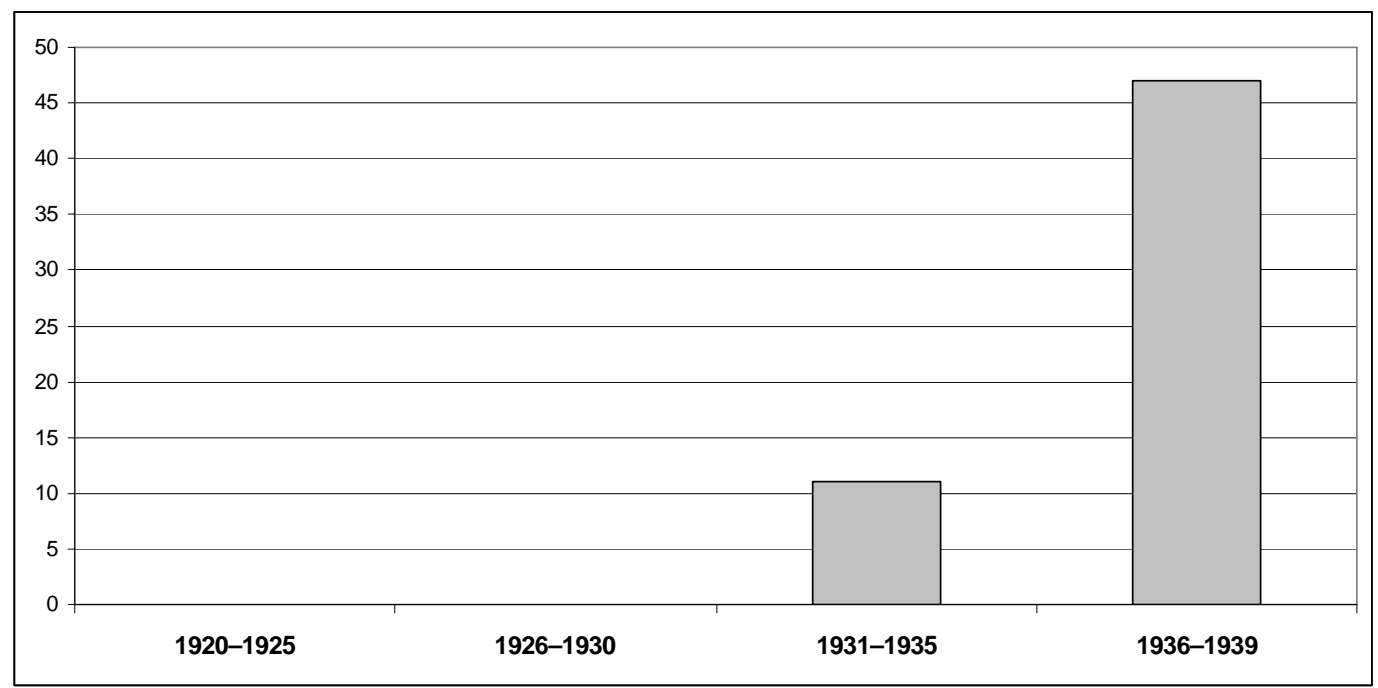

\section{Wykres 12a. Liczba tekstów, w których występuje nazizm, w ujęciu okołopięcioletnim}

Hipoteza T. Smółkowej o powojennej chronologizacji derywatu nazizm (Smółkowa 1976: 138) została obalona. Nazizm nie jest neologizmem (neonimem) współczesnej polszczyzny powojennej, ponieważ nazizm jest neologizmem (neonimem) 1. dekady lat 30. XX w. (1931-1935).

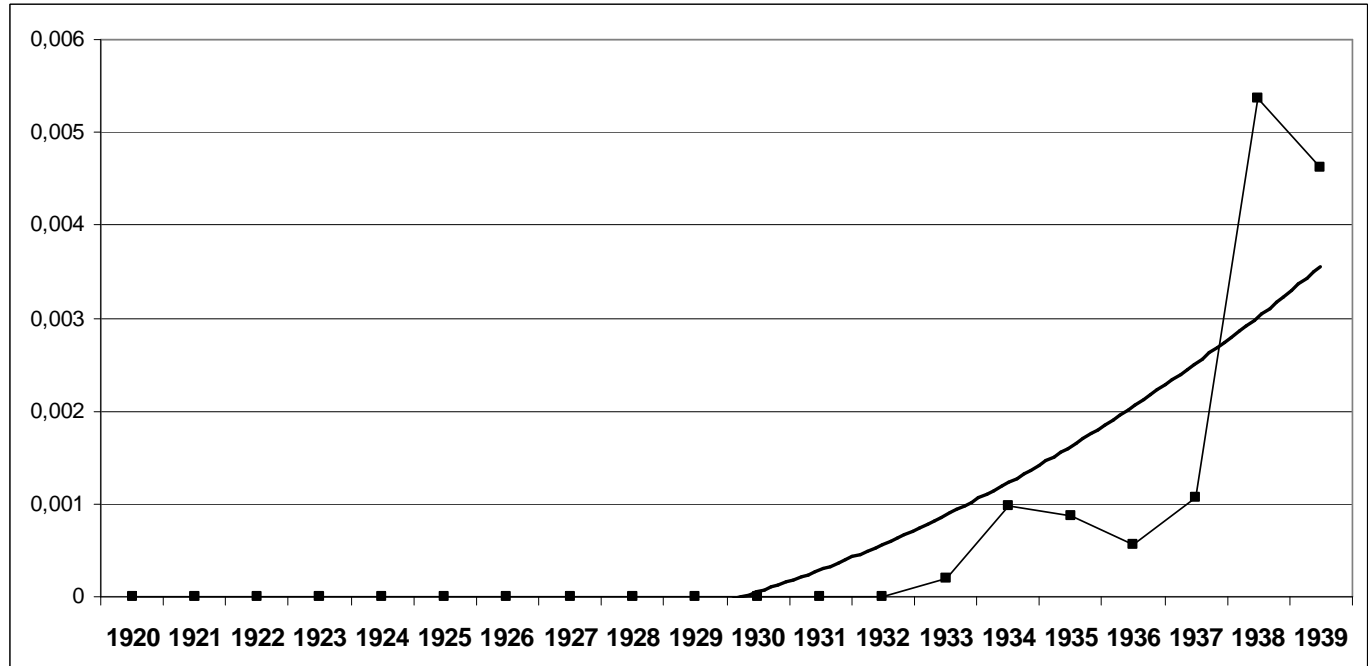

Wykres 12b. Frekwencja derywatu nazizm 


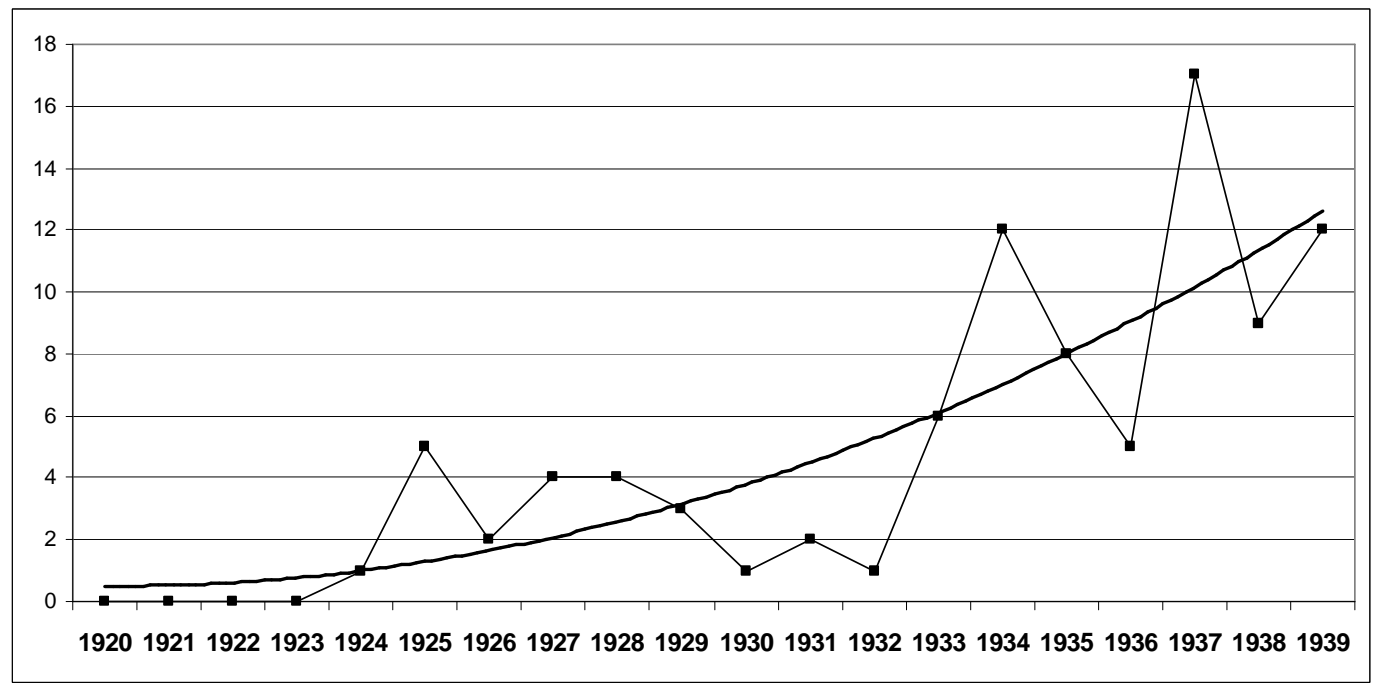

Wykres 13. Frekwencja derywatu opryskiwacz

Hipoteza T. Smółkowej dotycząca powojennej chronologizacji derywatu opryskiwacz (Smółkowa 1976: 142) została obalona.

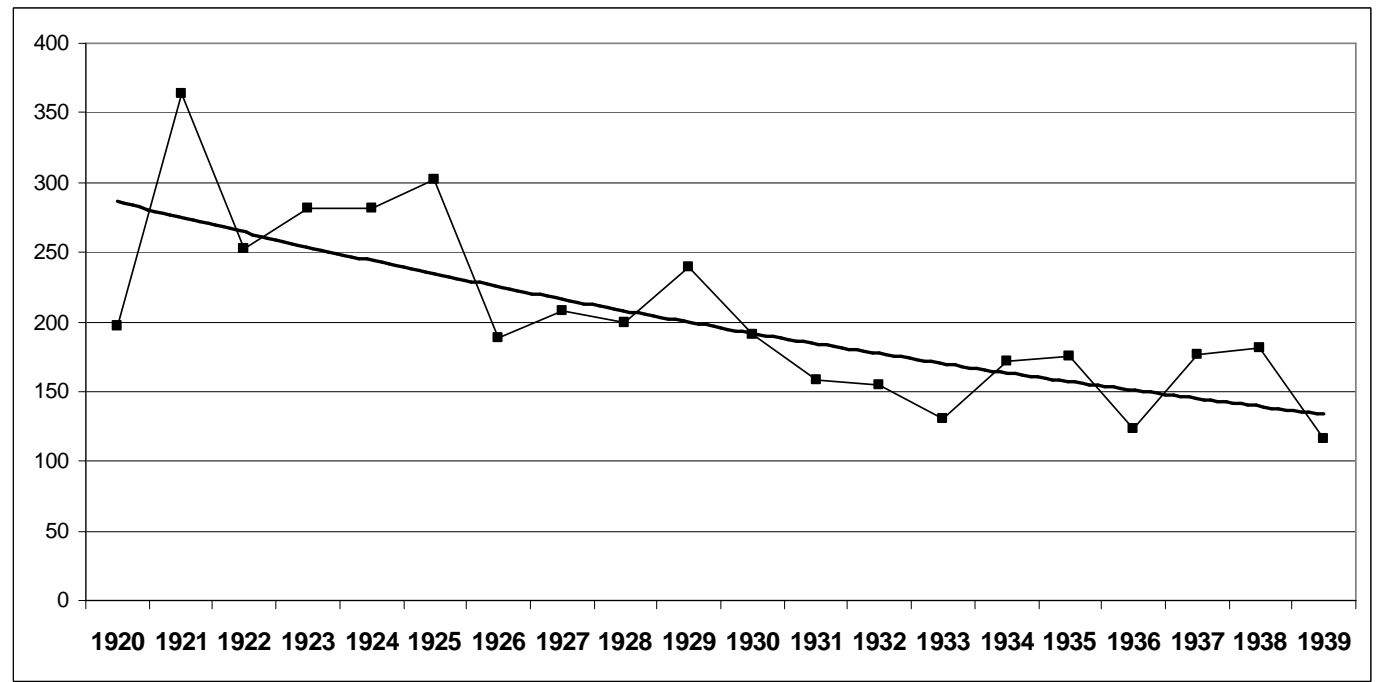

Wykres 14. Frekwencja frazemu/reproduktu kolej żelazna

Komentarz: Frekwencja frazemu kolej żelazna maleje w okresie 1920-1939 . 
Piotr Wierzchoń: Na jakie pytania mógtby odpowiedzieć tworzony $w$ 2. dekadzie XXI $w$. model leksykalno-derywacyjny polszczyzny XX $w$.?

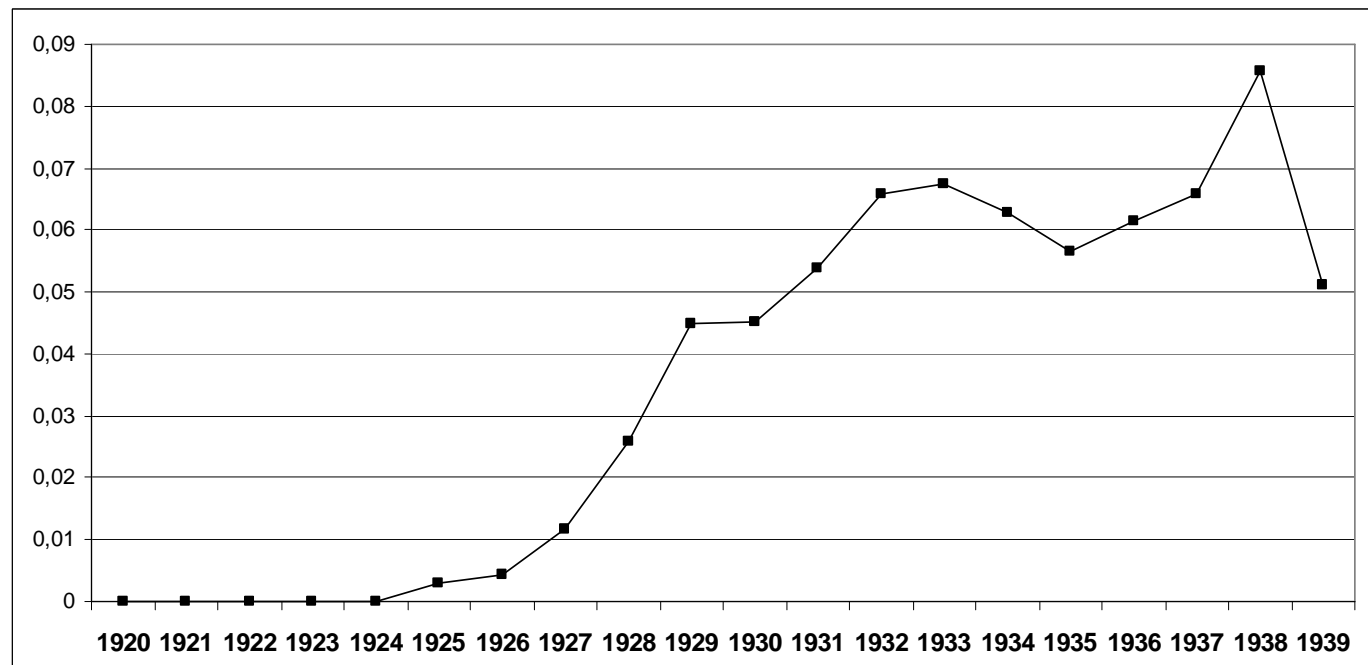

Wykres 15. Frekwencja derywatu taksówka

Komentarz: Taksówka to neonim z lat 20. XX w. Por. prapoczątki warszawskiej taksówki (taxis):

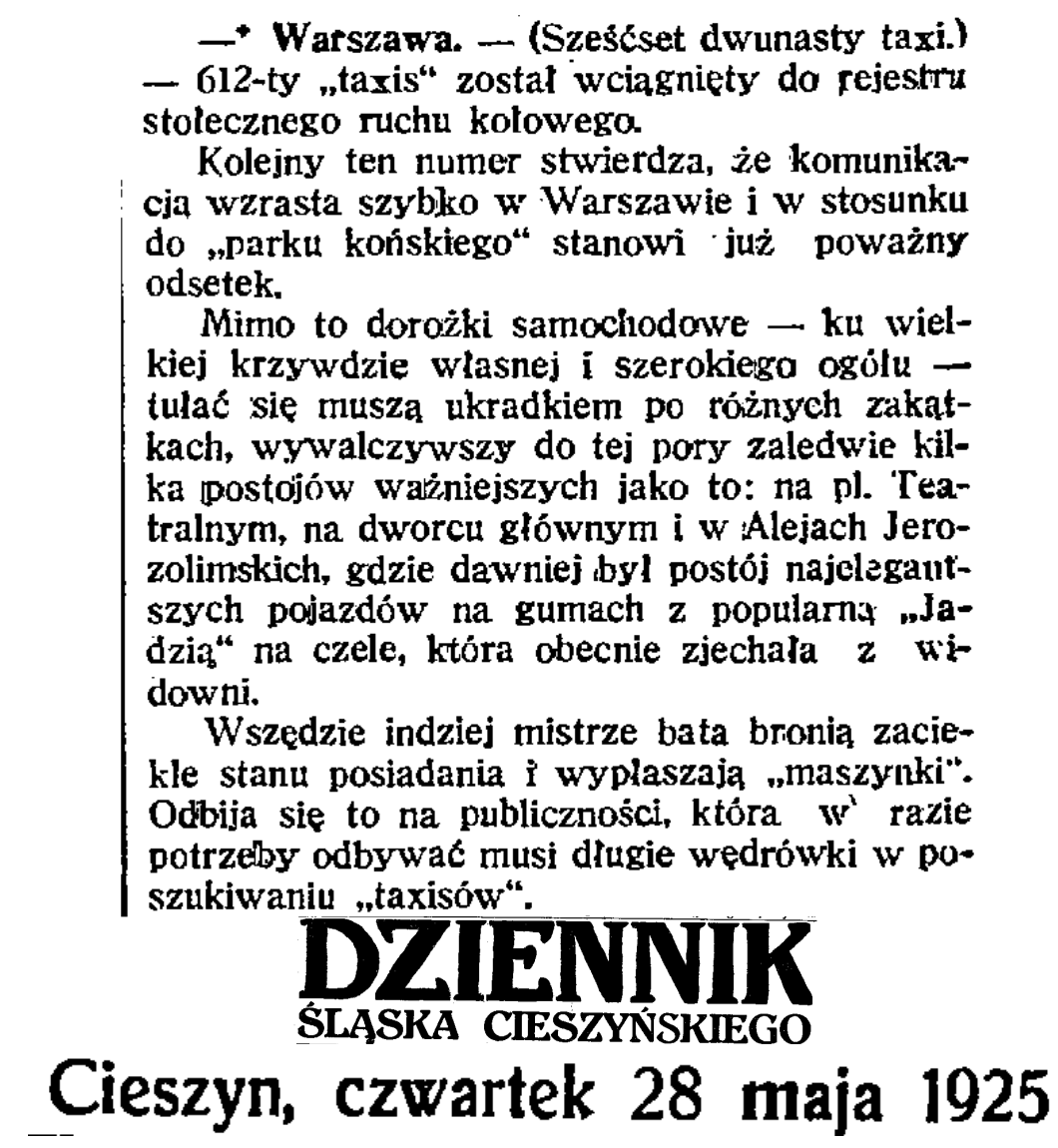




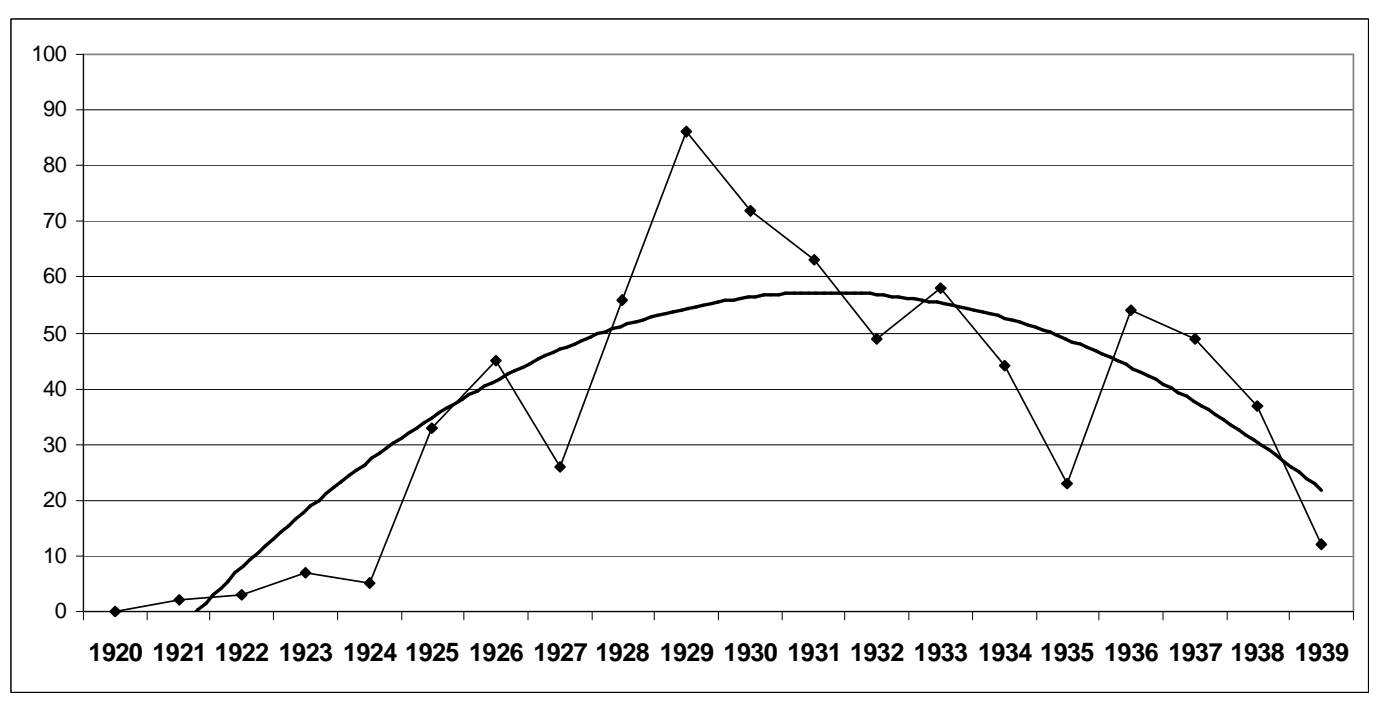

\section{Wykres 16. Frekwencja komplementarnego do derywatu tak- sówka frazemu/reproduktu dorożka samochodowa}

Komentarz: W związku ze wzrastającą liczbą samochodów osobowych przewożących pasażerów w miastach, a jednocześnie z językową tendencją do ekonomizacji, sprowadzającą się do usuwania elementów semantycznie niedostatecznie różnych (por. nawiązanie do koncepcji psychologicznej M. Rudnickiego) na korzyść elementu energetycznie mniej wymagającego (obca systemowi słowiańskiemu leksykalnie, choć przyswojona sufiksalnie taksówka kosztem dorożka samochodowa, przyswojona zresztą, to interpretacja zgodnie z duchem wypowiedzi H. Satkiewicz o związku substantywizowanych struktur - $k a$, który tu raczej nie zachodzi, bo nie ma bezpośredniej silnej frekwencyjnie motywacji podstawy *taksowy, chyba iżby lokutor polski pobrał ten właśnie z lat 30. przymiotnik z kolokacji typu optata taksowa, ewentualnie faktycznie rzeczownik ten byłby urobiony od przymiotnika taksowy z kolokacji jazda taksowa, ale który to sufiks i tak koreluje z morfologią polszczyzny środowiskowej, tu: środowisko przewoźników taxi), oraz w związku z przedwojennymi językowymi jaskółkami tendencji internacjonalizacyjnych (por. pracę niżej podpisanego Jaskótki przejawów internacjonalizacji...) oraz z tendencją do aksjologicznego dowaloryzowania elementów językowych obcych, w XX w. szczególnie anglosaskich, językowa forma taksówka wygrywa z dotychczasową dorożką samochodowa.

\section{Podsumowanie}

Wielkie modele leksykalno-derywacyjne polszczyzny, np. okresu staropolskiego (Kleszczowa 1998, 2003), XIX w. (Kwapień 2010), polszczyzny powojennej (Satkiewicz 1969, Smółkowa 1976, Smółkowa, Tekiel 1977), 2. poł. XX w. (Jadacka 2001), przełomu XX i XXI w. (Waszakowa 2005) itp., to wynik: 
Piotr Wierzchoń: Na jakie pytania mógtby odpowiedzieć tworzony $w$ 2. dekadzie XXI $w$. model leksykalno-derywacyjny polszczyzny XX $w$.?
a) żmudnych,
b) detalicznych,
c) szeroko zakrojonych,
d) wieloletnich

badań, prowadzonych głównie na materiale leksykograficznym (w pewnym zakresie modele H. Jadackiej i K. Waszakowej przyjmowały ekscerpty prasowe, w modelu K. Waszakowej - w dużym udziale, około 50\%, gromadzone własnoręcznie).

Zgromadzenie materiału do konstrukcji modelu leksykograficznego polszczyzny XX w. nie jest skomplikowane koncepcyjnie (należy znać tytuły słowników języka polskiego), ale jest wyczerpujące i wymagające operacyjnie (tzn. aby procedurę tę przeprowadzić, należy zaangażować pewien wypracowany, nieoczywisty ciąg dyrektyw, regulujących metodę pracy). Przykładowo, dla 1. poł. XX w. można przyjąć materiał ze Słownika warszawskiego, a dla 2. poł. XX w. materiał z Uniwersalnego stownika języka polskiego pod red. St. Dubisza (USJP). USJP jest ubazodanowiony, Słownik warszawski - nie (dlatego automatyzacja tego zadania jest relatywnie skomplikowana). Po uwzględnieniu pewnej dysproporcji kwantytatywnej można przystąpić do prac zmierzających do wypracowania założonego opisu polszczyzny XX w. (dla źródeł XIX-wiecznych drogę taką, poprzez wybór dzieł leksykografii XIX oraz przełomu XIX i XX w., wybrała np. E. Kwapień).

Trzeba szczególnie podkreślić, że powyższe modele wyrastają z pewnej tradycji konstrukcji leksykograficznych opisów polszczyzny. Tradycję tę, w ogólności, tak ujmuje cytowany na wstępie L. Fleck:

Jest pewien zespół ludzi o wspólnym stylu myślowym. Styl ten rozwija się i jest związany w każdym etapie ze swoją historją. Stwarza pewne określone pogotowie, udziela go członkom zespołu drogami socjologicznemi i dyktuje co i jak ci członkowie widzą. Obraz ten zjawia się naprzód jak wynik pewnego rodzaju eksperymentu myślowego: z zapasu tradycyjnych obrazów przymierza się pewne obrazy i ich kombinacje, potem odrzuca część, przestylizowuje inne, przechodzi pewnego rodzaju walkę $\mathrm{z}$ narzucającemi się naprzemiannie obrazami - aż wreszcie wytwarza się nowe pogotowie, t. j. pogotowie widzenia nowej, swoistej postaci. Zawiła ta droga jest badalna: teorja poznawania oparta o socjologję myślenia i socjologiczną historję rozwoju nauk może ją badać. Nauka ta, porównując różne style myślowe i badając krążenie myśli w obrębie różnych kolektywów myślowych, stwierdza, że poznawanie przechodzi trzy zasadnicze etapy: odkrycie zjawia się naprzód jako słabe awizo oporu hamującego naprzemienne oscylacje myślowe w twórczym chaosie myśli. $Z$ tego awiza powstaje drogą socjalnego stylizującego krążenia myśli udowodnialna, t. j. dająca się umieścić w stylowym systemie myśl. Dalszy rozwój zmienia ją w myśl - w ramach stylu - oczywistą, w postać swoistą, bezpośrednio poznawalną, w „przedmiot”, do 
którego członkowie kolektywu muszą się odnosić jako do faktu zewnątrz istniejącego, niezależnego od nich. Taka jest ewolucja tego co nazywamy „rzeczywistem” (Fleck 1935: $71)$.

Ważne jest tedy, aby połączyć najlepsze rozwiązania różnych kolektywów...

Z kolei model nieleksykograficzny polszczyzny XX w., postulowany w niniejszym artykule, wymaga metodologicznego wypracowania dostępu do materiału tekstowego (wypracowania teorii tego dostępu, np. TLCH), przykładowo prasowego. Zaletą z kolei tak wybranego materiału jest umożliwienie:

a) uwzględnienia informacji dotyczącej frekwencji tekstowej badanych derywatów, tj. ich częstości pojawiania się w tekstach,

b) kontynualnej obserwacji schronologizowanego materiału leksykalnego w obrębie lat 1901-2000, tj. w odstępie corocznym,

c) istotnego wzrostu materiału empirycznego, ekscerpowanego z realnych tekstów XX w. (z 3000-5000 jednostek leksykalnych do 50 000-100 ooo jednostek i więcej),

d) w wypadku ujęcia materiału z dLibry - systematycznego dotarcia do informacji geograficznych, prasoznawczych, topologicznych w zakresie występowania np. derywatu w tekście.

Niespekulacyjny, odpowiedzialnie przygotowywany opis projektu modelu polszczyzny XX w. musi zatem odpowiedzieć na pytania:

a) w jaki metodologiczny sposób zamierza się pozyskać leksykalny materiał empiryczny 1901-2000,

b) w jaki metodologiczny sposób zamierza się schronologizować ten materiał względem przyjętych w modelu granic datacji,

c) w jaki metodologiczny sposób (ze względu na jakie własności) zamierza się zbadać tak przygotowany w badaniach a) i b) materiał.

W wypadku piszącego te słowa odpowiedzi na powyższe punkty brzmią:

a) za pomocą $\boldsymbol{T L C H}$ (por. np. Wierzchoń 2008, 2010, 2011),

b) za pomocą $\boldsymbol{T L C H}$,

c) ze względu na zaproponowane w rozdziale 9. pytania (Q1.-Q37.).

Wskazuje się czasem, że ogół aktów składających się na $\boldsymbol{T L C H}$ to, z uwypukleniem lenizatora: „zaledwie”, czynności techniczne. Werbalne zapewnienia na ten temat, formułowane z intencją godzenia w $\boldsymbol{T L C H}$, jak i werbalne zapewnienia, że tak nie jest, formułowane $\mathrm{z}$ intencją promocji TLCH, nie mają żadnego faktycznego znaczenia. Rzeczywistość (a nie co innego) się dzieje... Tu ostatnia uwaga L. Flecka:

Trzeba stworzyć kierunkowe zainteresowania, trzeba zniszczyć wrogie zainteresowania. Trzeba stworzyć inne pogo- 
Piotr Wierzchoń: Na jakie pytania mógtby odpowiedzieć tworzony $w$ 2. dekadzie XXI $w$. model leksykalno-derywacyjny polszczyzny XX $w$.?

towie myślowe i wychować do niego ludzi. Jeśli się to uda, będą wszyscy biorący w niem udział widzieli nową postać wprost, bezpośrednio, naocznie, jakgdyby prawdę niezależną od ludzi, jedną, odwieczną. Dopiero następne przestrojenie pozwoli dostrzec, że miała ona swe stylowe uwarunkowanie i że była historycznie zdeterminowaną wypadkową (Fleck 1935: 75).

Kierunkowe zainteresowania lingwochronologizacyjną analizą polszczyzny XX w., prowadzącą do ustalenia precyzyjniejszych niż dotąd neonimicznych hipotez chronologizacyjnych, np. względem przełomu doby nowopolskiej a „współczesności”, tj. przełomu II wojny światowej, piszący te słowa tworzy poprzez wskazanie, że motyczkowanie (Jadacka 2001: 183) to nie jest neonim powojenny (por. Wierzchoń 2008: z okładki). Ktoś, kogo zaciekawi ten fakt, być może zainteresuje się tym, że i dehydratacja (Waszakowa 2005: 234) nie jest neonimem powstałym po roku 1985. Ten, kto postawi więcej tego typu pytań (por. np. $5 \times 100 \mathrm{w}$ : Wierzchoń 2008), zmierzających do weryfikacji chronologizacyjnej materiału nowopolskiego, będzie - o ile go to zainteresuje - w konsekwencji próbował odpowiedzieć na pytanie: dlaczego i motyczkowanie, i dehydratacja zostały uznane za neonimy względem danej granicy datacji? Kolejno ten ktoś sprawdzi, że repasacja, ujęta w SJPD bez żadnego potwierdzenia tekstowego, traktowana jest w modelu T. Smółkowej (1976: 151) także jako neonim powojenny (lecz przed II wojną światową działały w Polsce warsztaty repasacji pończoch, co rejestrują przedwojenne Spisy abonentów sieci telefonicznych). Pojawia się pytanie: jaki ciąg czynów, regulowanych jakimi dyrektywami, spowodował to ustalenie? Próbować odpowiedzieć na to pytanie to $\mathrm{w}$ innym wysłowieniu: zrekonstruować budowę teorii lingwochronologizacyjnych, które prowadziły do ustalenia tych chronologizacji neonimicznych. Rozwój wiedzy naukowej zakłada korektę programów nieefektywnych. Programem nieefektywnym jest program oparty na kryterium leksykograficznym nowości (program stosowany w serii Nowe stownictwo polskie). Rodzi się nowy, konkurencyjny program, odwołujący się do głównej myśli J. Wawrzyńczyka, wykorzystujący kryterium tekstowe (czyli: $\boldsymbol{T L C H}$ ), a więc ustanowiła się kontroferta dwu programów (teorii) lingwochronologizacyjnych.

Następnie ktoś inny sięgnie po jeden z tomów serii Nowe stownictwo polskie i sprawdzi tam, że np. sepsa, jako jednostka współczesnej polszczyzny, chronologizowana jest na rok 2000. Ale sepsa (np. sepsa popołogo$w a)$ występuje w tekstach przedwojennych, tj. z lat 20. XX w. Dlatego badacz współczesnej polszczyzny dysponuje obecnie dwiema chronologizacjami z dwu modeli polszczyzny XX w., a więc:

a) sepsa to jednostka leksykalna z roku 2000,

b) sepsa to jednostka leksykalna z roku 1921.

Dodatkowo, Stownik bibliograficzny języka polskiego Jana Wawrzyńczyka ustala chronologizację: 
c) sepsa to jednostka leksykalna z roku 1940.

Badacze, którzy wolą wybrać powojenną chronologizację sepsy, czyli z okresu „współczesności”, będą się odwoływali do chronologizacji z roku 2000.

Inni badacze, którzy wolą wybrać wcześniejszą chronologizację sepsy, poświadczoną w źródłach z lat 40., wybiorą tę chronologizację, aby zredatować treść hipotezy z roku 2000.

Jeszcze inni badacze polszczyzny XX w. wybiorą chronologizację z roku 1921.

Tak więc istnieją obecnie w kraju trzy hipotezy chronologizacyjne sepsy:
a) lata 2000 .
b) lata 40 .
c) lata 20 .

Biorąc pod uwagę te trzy hipotezy (i tysiące innych), można zbudować trzy modele polszczyzny XX w., jej rozwoju, procesu przyjmowania nazw, idei, pojęć, ewolucji semantycznej itp.

Podobnie wygląda problem chronologizacji tzw. neosemantyzmów, a więc jednostek, które np. w serii Nowe stownictwo polskie uzyskują znak *, przykładowo: wibrator* (Smółkowa 1999: 276). Wibrator chronologizowany jest na rok 1990, tymczasem urządzenia o tej nazwie i identycznej funkcji znane były powszechnie w 1. poł. XX w. (świadczą o tym np. ogłoszenia prasowe zachęcające potencjalne klientki do nabywania tego dobra czy relacje z wystaw aparatów i artykułów elektrycznych, np. w „Dzienniku Śląska Cieszyńskiego" z roku 1925). Na chronologizacji z Nowego stownictwa polskiego zaciążyło kryterium leksykograficzne. SJPD z pewnych względów nie wyróżnił jednostki leksykalnej wibrator (elektryczne urządzenie do masażu intymnego). Ale teksty przedwojenne notują użycia tej jednostki (także w ortografii vibrator). Urządzenie takie (przenośne, elektryczne, o wiadomej funkcji i grupie docelowej) istniało w okresie polszczyzny nowopolskiej, czyli do roku 1939. Analiza składu polimerów służących do produkcji urządzeń elektrycznych tego typu, obserwacja gamy kolorystycznej, wachlarza kształtu itp. na pewno wykaże, że wibratory z lat 20. i 9o. XX w. to inne polimerowo, kolorystycznie, cenowo itp. obiekty. Ale wówczas pojawia się nowe pytanie: na czym polega różnica semantyczna $\mathrm{w}$ eksplikacji ewentualnej pary homonimicznej: wibrator $_{1}$ i wibrator ${ }_{2}$, tj. wibrator ${ }_{1-1925}$ i wibrator ${ }_{2-1990}$. I czy wprowadzenie tej różnicy, od której należałoby już chronologizować wibrator ${ }_{2}$ w nowym szeregu chronologizacyjnym, np. 1990-, nie spowoduje, że leksykografię polską należałoby przeformułować, tak iżby bezwyjątkowo dla każdego możliwego urządzenia (np. radio) wyróżniać dwa szeregi niehomoleksyjnych jednostek języka (np. aparat radiowy przedwojenny i aparat radiowy powojenny). Szeregi takie, oczywiście, można laboratoryjnie ustanowić dla 2-4 przykładów, ale żadna leksykografia żadnego języka naturalnego rozróżnienia takiego 
Piotr Wierzchoń: Na jakie pytania mógtby odpowiedzieć tworzony $w$ 2. dekadzie XXI $w$. model leksykalno-derywacyjny polszczyzny XX $w$.?

w sposób systematyczny (a nie ilustracyjno-laboratoryjny, jak tu właśnie) nie uniesie $\mathrm{w}$ masie swojego zadania: chronologizacji dziesiątek tysięcy jednostek.

Na przełomie 1. i 2. dekady XXI w. wytworzyło się napięcie pomiędzy dwoma teoriami z dwoma prawami neonimicznymi:

a) kryterium leksykograficznym (SJPD i SJPSz) a

b) kryterium tekstowym.

Chwilowo (2008-2011) do oceny tych teorii nie są dopuszczane takie warunki, jak np. moc eksplanacyjna, najlepsze potwierdzenie itp., a przeważa kryterium tradycji czy autorytetu (np. piszący te słowa nie ma żadnego autorytetu lingwochronologizacyjnego, dlatego - jako podmiot poznania lingwochronologizacyjnego, polegającego na tworzeniu modelu chronologizacyjnego i rechronologizacyjnego polszczyzny XX w., oraz poznania metalingwochronologizacyjnego, polegającego na logicznej rekonstrukcji polskich programów chronologizacyjnych - automatycznie staje na tzw. przegranej pozycji i jego wysiłek - wyrażający się w porcji argumentacji - który musi ponieść, jest niewspółmiernie większy w stosunku do wysitku badaczy promujących kryterium leksykograficzne neonimiczności; doszło tu do paradoksalnej sytuacji: sztuczna, tj. z pominięciem powyższych warunków oceny, negacja $\boldsymbol{T L C H}$, wykorzystująca wzorce oceny, w których nie mówi się o $\boldsymbol{T L C H}$, tylko o czymś innym, powoduje konieczność podjęcia jeszcze bardziej wytężonej pracy badawczej, która w sposób mierzalny, np. poprzez wynik kwantytatywny ujęty w Depozytorium leksykalnym języka polskiego, przekonuje o zasadności stosowania dziś kryterium tekstowego w opisie polszczyzny XX w.).

Kolejno pojawia się (u tych, u których się pojawia) Fleckowskie pogotowie myślowe: który program wybrać w celu ewentualnego opracowania modelu leksykalno-derywacyjnego polszczyzny XX w.? Zarówno program serii Nowe stownictwo polskie, jak i program TLCH „wychowuje”, na co zwraca uwagę Fleck, ludzi. Jeżeli metodzie fotodokumentacyjnej, czyli postleksykografii, uda się w przyszłości (np. za kilka czy kilkanaście lat) „wychować” więcej ludzi, tj. więcej ludzi uzna, że kryterium tekstowe neonimiczności jest efektywniejszym kryterium rozstrzygania np. tego, które jednostki powstały po roku 1945, a które przed (np. motyczkowanie i dehydratacja), wówczas wytworzy się stan, w którym „wszyscy biorący w niem udział widzieli nową postać wprost, bezpośrednio, naocznie, jakgdyby prawdę niezależną od ludzi, jedną, odwieczną".

\section{Cytowna literatura}

Burkacka, I., Pawelec, R., Zdunkiewicz-Jedynak, D. (red.). 2010, Stowa kładki, na których spotykają się ludzie różnych światów. Warszawa.

Dubisz, St., Gajda, S. (red.). 2001. Polszczyzna XX wieku. Ewolucja i perspektywy rozwoju. Warszawa. 
Dunaj, B. 2010. Perspektywy badań historycznojęzykowych. „LingVaria” 2(10).

Fleck, L. 1935. O obserwacji naukowej i postrzeganiu wogóle. „Przegląd Filozoficzny" 38.

Grobler, A. 2001. Pomysty na temat prawdy i sposobu uprawiania filozofii w ogóle. Kraków.

Jadacka, H. 1978. O interpretacji derywatów przymiotnikowych z sufiksem-awy. „Poradnik Językowy” 4.

Jadacka, H. 2001. System stowotwórczy polszczyzny (1945-2000). Warszawa.

Kay, Ch., Roberts, J., Samuels, M., Wotherspoon, I. (red.). 2009. Historical Thesaurus of the Oxford English Dictionary. Oxford.

Kleszczowa, K. 1998. Staropolskie kategorie stowotwórcze i ich perspektywiczna ewolucja. Rzeczowniki. Katowice.

Kleszczowa, K. 2003. Staropolskie derywaty przymiotnikowe $i$ ich perspektywiczna ewolucja. Katowice.

Kozielecki, J. 1972. Osobliwości procesu myślenia a twórczość naukowa. „Zagadnienia Naukoznawstwa” 8.

Kwapień, E. 2010. Kształtowanie się zasobu leksykalnego polszczyzny XIX w. - rzeczowniki (na podstawie danych leksykograficznych). Warszawa.

Majdak, M. 2008. Stownik warszawski: koncepcja - realizacja - recepcja. Warszawa.

Matyka, A. 2010. O pojęciu neologizmu w językoznawstwie. W: Burkacka, I., Pawelec, R., Zdunkiewicz-Jedynak, D. (red.). 2010.

Mazurek, C., Stroiński, M., Węglarz, J. (red.). 2011. Polskie Biblioteki Cyfrowe 2010. Materiaty $z$ konferencji zorganizowanej $w$ dniach 20-21 października 2010 roku przez Bibliotekę Kórnicka PAN, Poznańska Fundację Bibliotek Naukowych, Poznańskie Centrum Superkomputerowo-Sieciowe. Poznań.

Mędelska, J. 2004. Język polskiej prasy wileńskiej (1945-1979). T.3. Lata 1960-1979. Cz. 2 - Stownictwo, wyrazy. Bydgoszcz.

Nęcka, E. 1994. TRoP... Twórcze rozwiąywwanie problemów. Kraków.

Nowakowska, B. 2005. Nowe połaczenia we wspótczesnej polszczyźnie. Kraków.

Pogonowski, J. 1991. Hierarchiczne analizy języka. Poznań.

Przełęcki, M. 1993. Prawda. „Filozofia Nauki” 2-3.

Rudnicka, E. 2010. Leksykograficzne egzemplum. Sposoby wykorzystania cytatów i kolokacji $w$ polskich stownikach ogólnych. W: Burkacka, I., Pawelec, R., Zdunkiewicz-Jedynak, D. (red.). 2010.

Satkiewicz, H. 1969. Produktywne typy słowotwórcze współczesnego języka polskiego. Warszawa.

Smółkowa, T. (red.). 1998. Nowe stownictwo polskie. Materiaty z prasy lat 1985-1992. Cz. I. Kraków.

Smółkowa, T. (red.). 1999. Nowe stownictwo polskie. Materiały z prasy lat 1985-1992. Cz. II. Kraków. 
Piotr Wierzchoń: Na jakie pytania mógtby odpowiedzieć tworzony $w$ 2. dekadzie XXI $w$. model leksykalno-derywacyjny polszczyzny XX $w$.?

Smółkowa, T. 1976. Nowe stownictwo polskie. Badania rzeczowników. Wrocław.

Smółkowa, T., Tekiel, D. 1977. Nowe stownictwo polskie. Przymiotniki i przystówki. Wrocław.

Such, J. 1975. Problemy weryfikacji wiedzy. Warszawa.

Szczyszek, M. 2006. Derywaty z przyrostkiem -owicz $w$ języku polskim (dobra nowopolska). Poznań.

Szczyszek, M. 2010. Przejawy internacjonalizacji we współczesnej polszczyźnie na przykładzie zjawisk słowotwórczych. „Linguistica Copernicana” 2(4).

Waszakowa, K. 1991. O wartościowaniu $w$ stowotwórstwie. „Poradnik Językowy" 5-6.

Waszakowa, K. 1994. Stowotwórstwo współczesnego języka polskiego. Rzeczowniki sufiksalne obce. Warszawa.

Waszakowa, K. 2005. Przejawy internacjonalizacji $w$ stowotwórstwie wspótczesnej polszczyzny. Warszawa.

Wawrzyńczyk, J. 1987. W sprawie materiałów do tezaurusa polszczyzny dwudziestowiecznej. Łódź.

Wawrzyńczyk, J. 1992. Chronologizacja stownictwa nowopolskiego. W poszukiwaniu źródet dokumentacyjnych neologizmów powojennych. Toruń.

Wawrzyńczyk, J. 1994. Tak zwane nowe stownictwo polskie $w$ świetle dokumentacji „Polskiego Informatorium Wyrazowego”. Katowice.

Wawrzyńczyk, J. 1999. Nowe stownictwo polskie. Fikcje i fakty. Warszawa.

Wawrzyńczyk, J. 200o. Stownik bibliograficzny języka polskiego. Wersja przedelektroniczna. Tom I. Warszawa.

Wawrzyńczyk, J. 2008. Z leksykografii chronologizacyjnej. I Polskie przymiotniki. Warszawa.

Wierzchoń, P. 2008. Fotodokumentacja. Chronologizacja. Emendacja. Teoria i praktyka weryfikacji materiału leksykalnego $w$ badaniach lingwistycznych. Poznań.

Wierzchoń, P. 2010. Depozytorium leksykalne języka polskiego. Nowe fotomateriaty z lat 1901-2010. Tom I. Warszawa. 